\title{
INSULAR WOODINESS ON THE CANARY ISLANDS: A REMARKABLE CASE OF CONVERGENT EVOLUTION
}

\author{
Frederic Lens, ${ }^{1, *}$ Nicolas Davin, ${ }^{*}$ Erik Smets, ${ }^{*}+$ and Marcelino del Arcoł \\ *Naturalis Biodiversity Center, Leiden University, P.O. Box 9514, 2300RA Leiden, The Netherlands; +Ecology, Evolution and Biodiversity \\ Conservation Section, Katholieke Universiteit Leuven, Leuven, Belgium; and ¥Department of Plant Biology (Botany), \\ La Laguna University, 38071 La Laguna, Tenerife, Spain
}

Premise of research. One of the most conspicuous aspects of island floras is the relatively high proportion of woody species. Often, but not always, these woody species have developed wood on the islands and have evolved from herbaceous continental ancestors, a phenomenon known as insular woodiness. Shifts from herbaceousness toward increased woodiness also occur on continents (the broader term "secondary woodiness" is more appropriate here and includes insular woodiness), but comprehensive worldwide knowledge about secondary woodiness within angiosperms remains lacking. We update hypotheses regarding the herbaceous ancestry of woody Canarian lineages in a molecular phylogenetic context and investigate the possible link of secondary woodiness and paedomorphic wood features in the Carlquistian sense.

Methodology. We have assembled available literature data from molecular phylogenetic studies, wood anatomical descriptions, floras, and taxonomic revisions to identify the native secondarily woody taxa.

Pivotal results. In total, at least 220 native Canary Island species of flowering plants, from 34 genera representing 15 families, are truly insular woody. This represents a significant portion of the native nonmonocot angiosperm species on the Canaries, and all of the insular woody species have paedomorphic wood features in the Carlquistian sense, although this wood anatomical syndrome might be more related to particular life forms. The majority of these insular woody groups typically grow in the markedly dry lowland regions, suggesting a possible link between secondary woodiness and increased drought resistance.

Conclusions. The Canary Island flora is characterized by at least 38 independent shifts toward insular woodiness, representing an important portion of the endemic angiosperms on the archipelago. These convergent evolutionary events emphasize the remarkable lability in growth forms between herbaceous and woody lineages, but it remains puzzling which environmental variables trigger these shifts and how these independent shifts are regulated genetically.

Keywords: Canary Islands, convergent evolution, insular woodiness, molecular phylogeny, protracted juvenilism, secondary woodiness, wood anatomy.

Online enhancements: appendix tables.

\section{Introduction}

Darwin's five-year odyssey aboard the HMS Beagle was the beginning of numerous discoveries of unknown life forms that formed the basis for his pioneering evolutionary theory (Darwin 1859). Not surprisingly, his ideas originated when he visited islands, which are still considered to be laboratories of evolution because of their isolated position and relatively small size, in combination with a high diversity in habitats and an often dynamic geological history in terms of volcanic and erosional activity (Carlquist 1974; Givnish 1998; Emerson 2002; Whittaker et al. 2008; Losos and Ricklefs 2009; Whittaker and Fernández-Palacios 2010; Bramwell and Caujapé-Castells 2011). Gigantism in relatives of small continental animals or flightlessness in birds are examples of insular animal evolution,

${ }^{1}$ Author for correspondence; e-mail: frederic.lens@naturalis.nl.

Manuscript received September 2012; revised manuscript received February 2013; electronically published August 7, 2013. but insular floras also typically include species with remarkable adaptations, such as a pronounced development of woodiness. This so-called insular woodiness was described and interpreted correctly by Darwin:

Again, islands often possess trees or bushes belonging to orders which elsewhere include only herbaceous species; now trees ... generally have, whatever the cause may be, confined ranges. Hence trees would be little likely to reach distant oceanic islands; and an herbaceous plant, ... when established on an island and having to compete with herbaceous plants alone, might readily gain an advantage by growing taller and taller and overtopping the other plants. If so, natural selection would often tend to add to the stature of herbaceous plants when growing on an island, to whatever order they belonged, and thus convert them first into [insular woody] bushes and ultimately into trees. (Darwin 1859, p. 392)

Darwin's hypothesis that at least some woody island species evolved wood on the islands and are thus derived from continental herbaceous colonizers is supported by recent molec- 
ular phylogenetic results for many woody island genera: to name just a few, Aeonium and Echium on the Canary Islands (Böhle et al. 1996; Mes and 't Hart 1996); Viola and the silverswords Argyroxiphium, Dubautia, and Wilkesia on the Hawaiian islands (Baldwin et al. 1991; Ballard and Sytsma 2000); Eryngium and Senecio (formerly Robinsonia) on the Juan Fernandez Islands (Calviño et al. 2010; Pelser et al. 2010b); Dendrosicyos on Socotra (Schaefer et al. 2009); $\mathrm{Ne}$ sohedyotis on St. Helena (Lens et al. 2009); and Fitchia and Plakothira on Polynesian islands (Hufford et al. 2003; Crawford et al. 2009). Darwin's insular-woodiness hypothesis is further supported by (1) the excellent dispersal mechanisms of many herbaceous plant groups that have reached isolated islands, (2) the relatively young age ( $5 \mathrm{Myr}$ or less) of several insular woody groups, based on molecular divergence estimates (Baldwin and Sanderson 1998; Carine 2005; Fiz et al. 2008; Kim et al. 2008; Feodorova et al. 2010), and (3) the presence of specific wood features in these secondarily woody species ("paedomorphosis" sensu Carlquist 1962; "protracted juvenilism” sensu Carlquist 2009, 2012); molecular phylogenies have confirmed the evidence for an herbaceous ancestry adduced well before the molecular era (Carlquist 1962, 1969a, 1969b, 1970a, 1970b, 1970c, 1974, 1985; Carlquist and Eckhart 1982; Cumbie 1983; however, see "Discussion" about interpreting this wood anatomical syndrome).

Insular woody species do not comprise the entire island flora, as is evident from the following three points. First, several authors have advocated that many of the woody island species can best be interpreted as evolutionary remnants of ancient lineages instead of as recent lineages, because it wasand still is-generally accepted that the shift from (primary) woodiness toward herbaceousness is much more common than the opposite shift (i.e., from herbaceousness toward secondary woodiness) in flowering plants (Lems 1960; Bramwell 1972; Cronk 1987, 1992). The evergreen laurel forests in the Canary Islands, dating back 65 Myr (paleotropical flora with Thetian-Tertiary origin; Fernández-Palacios et al. 2009; fig. 1A) and composed mainly of primarily woody trees having only woody relatives, provide one of the best-known examples demonstrating the validity of this relict hypothesis. Second, our ongoing broad-scale attempt to review habit shifts from herbaceousness toward increased woodiness within angiosperms shows that a majority of them (more than 200 genera, including at least one secondarily woody species) do not occur on islands (F. Lens, unpublished data). For these woody continental taxa, the term "insular woodiness" should be replaced by the more general term "secondary woodiness" to define all woody taxa characterized by an herbaceous ancestry; "insular woodiness" should be applied only to woody island taxa that have developed woodiness on the islands, and it should be considered part of the broader term "secondary woodiness." Therefore, not all woody island species with an herbaceous ancestry are by definition insular woody. For instance, the woody genus Scalesia, endemic to the Galapagos Islands, is secondarily (not insular) woody, because its closest relatives are the woody Andean Pappolobus species (Schilling et al. 1994); the woody Scalesia-Pappolobus clade is embedded in a largely herbaceous group consisting of Helianthus, Simsia, and Viguiera pro parte. The same is true for the woody Hawaiian lobeliads, which are secondarily woody (Givnish et al.
2009). Third, insular floras still include a significant proportion of herbaceous species that apparently did not evolve into shrubs or trees, for whatever reason. In conclusion, it is also important to critically examine the origin of woodiness of native woody island plants when they belong to families with many insular woody species (e.g., Asteraceae).

Since the number of secondarily woody genera within angiosperms is much higher than anticipated (F. Lens, unpublished data), we decided to focus first on the Canary Islands, an active volcanic archipelago off the coast of West Africa that includes seven main islands ranging in age from 1 to $21 \mathrm{Myr}$ (Coello et al. 1992). This archipelago is unique, compared to other oceanic islands, for two main reasons: (1) the dynamic link between island age (increasing from west to east) and height, which results in marked habitat differences and strong influences of humid trade winds on the northeastern mountain slopes of the higher islands; and (2) the proximity of the African mainland and the presence of several volcanic sea mounts around the Canary Islands, which may have facilitated dispersal between the continent and the archipelago by serving as "stepping stones" during glacial periods, when sea levels were lower (García-Talavera 1997; Geldmacher et al. 2001; Fernández-Palacios et al. 2009).

This review on the Canary Islands has several main objectives: (1) to give a sound estimate of the minimum number of insular and secondarily woody species and to identify the number of habit shifts, based on a molecular phylogenetic context and wood anatomical observations, (2) to discuss the association of secondary woodiness with paedomorphic wood characters in the Carlquistian sense, (3) to comment on the recent versus relict origin of insular woody groups, and (4) to bring forward some arguments for a new hypothesis linking secondary woodiness with drought resistance for several groups in the Canary Islands and beyond.

\section{Material and Methods}

As explained above, not all woody island groups are insular woody. Therefore, it is crucial to distinguish between insular woody species that have developed into shrubs on the islands, secondarily woody species that have developed wood from a continental (secondarily) woody ancestor, and primarily woody species derived from continental (primarily) woody relatives. The first difficulty is how to distinguish woody from herbaceous species. In nonmonocot flowering plants, this is not so straightforward as it may seem, because the anatomical boundary between herbaceous and woody species is known to be fuzzy (Lens et al. 2012a). Most angiosperm herbs of the traditional dicot lineages produce various amounts of wood tissue at the basal part of the stem, even in small, herbaceous species such as Arabidopsis thaliana (Carlquist 2009; Dulin and Kirchoff 2010; Schweingruber et al. 2011; Lens et al. $2012 b$ ). The amount of wood development in herbaceous stems is always limited, ranging from just a few wood cells in the vascular bundles to a narrow, complete wood cylinder, while in woody species there is a gradual increase in the wood cylinder that usually extends into the upper parts of the branches. However, it remains challenging to draw the line between herbaceous and truly woody species, even in groups where detailed diameter measures of entire stems and wood 

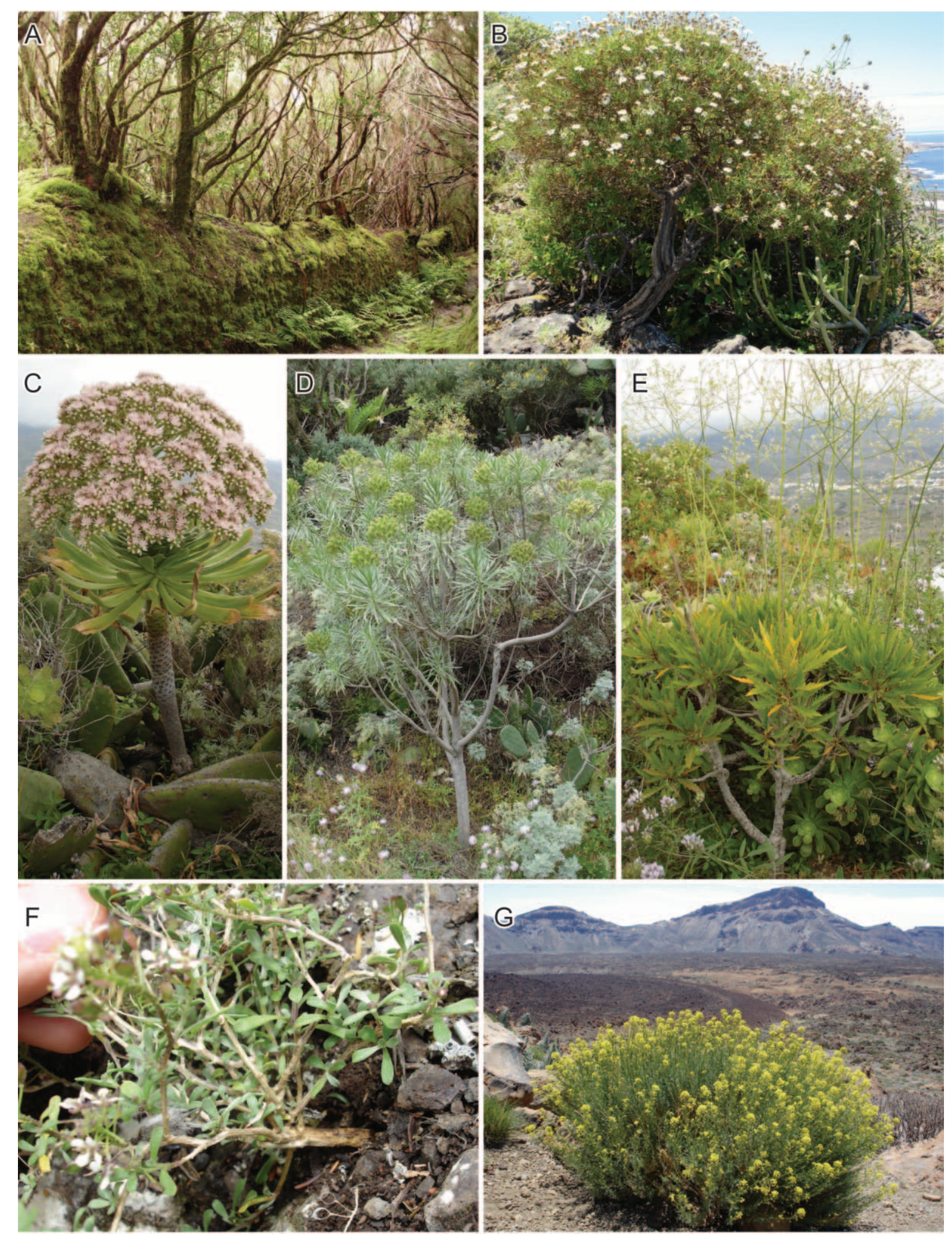

Fig. 1 Illustrations of the woody habit of Tenerife species. A, Overview of laurel forest with primarily woody species in Anaga, close to Casa Forestal, Tenerife. B-G, Truly insular woody species. B, Argyranthemum frutescens. C, Aeonium urbicum. D, Echium leucophaeum. E, Crambe arborea. F, Lobularia canariensis. G, Descurainia bourgeauana. 
cylinders were made in combination with detailed wood anatomical observations (Lens et al. 2012a). Therefore, in order not to overestimate the number of insular or secondarily woody taxa, we prefer to exclude any life form intermediate between herbaceousness and woodiness, and we discard theoften confusing-transitional life forms that are mentioned in species descriptions: among others, "suffrutescent herbs," "lignified herbs," "woody herbs," "herbs or subshrubs," and "weakly lignified shrublets." The insular woody shrubs that we identified on the Canary Islands are mostly small shrubs, rarely exceeding $2 \mathrm{~m}$ tall (fig. $1 B-1 G$ ), and occasionally small trees or climbing species up to $5 \mathrm{~m}$.

From the continuous anatomical variation between herbaceous and woody species, it is not surprising that botanists interpret the term "woodiness" in different ways and often make their decisions without any anatomical observations, which further complicates things. For instance, in the molecular phylogeny of Pericallis (Asteraceae), Panero et al. (1999) sequenced 15 species, of which six were considered woody. In our interpretation, only Pericallis appendiculata can be considered a truly woody shrub; the five other so-called woody species would be better interpreted as herbaceous species with a woody basal part, meaning that Panero et al.'s hypothesis of two independent shifts toward insular woodiness is not valid. Another example is the molecular phylogenetic study of Tolpis by Moore et al. (2002), who concluded that woodiness arose in the common ancestor of all extant Tolpis, followed by two independent reversals to an herbaceous habit. Although there is indeed an anatomical difference in wood formation among different Tolpis species, this difference is only trivial, so we have excluded this genus from our analysis of woody species. The same is true for the Crassulaceae genera Aichryson and Monanthes. When two literature sources contradict each other-for instance, Mes and 't Hart (1996) considered fewer Aeonium species to be woody than did Bramwell and Bramwell (1974) - the stricter circumscription of woodiness (in this case, that of Mes and 't Hart 1996) was followed.

After the life forms were defined, the next step was to assemble independent molecular and anatomical data, because investigating merely wood anatomical characters or molecular phylogenetic data may easily lead to misinterpretation of the origin of woodiness in a particular group (Lens et al. 2009, 2012a; Dulin and Kirchoff 2010). Therefore, we consulted 61 molecular phylogenetic publications about Canary groups that included herbaceous as well as woody species, and we retrieved habit and habitat information for the species used in these phylogenies based on 47 revisions and flora volumes. Furthermore, we searched for wood anatomical features with protracted juvenilism in 23 wood anatomical papers and in original sections of wood samples that we collected during our Tenerife expedition in spring 2011. The sections were made according to a previously described standard protocol (Lens et al. 2007). Our sections were screened for the presence of an abundance of upright and square cell shapes of ray cells and for flat or decreasing length-on-age curves for vessel elements, two wood characters that are frequently used to point to secondarily woody taxa (fig. 2; however, see "Discussion" on how to interpret this). We have used a comprehensive phylogenetic framework to assess whether Carlquistian paedomorphic features are present only in secondarily woody species or whether these features represent a particular function that could explain their presence in secondarily as well as primarily woody species with similar growth forms. For a list of other examples of protracted juvenilism in wood, we refer to Carlquist $(2009,2012)$.

\section{Results}

The results of this literature search are summarized in table 1 (woody taxa with clearly herbaceous origin) and the appendix, available in the online edition of the International Journal of Plant Sciences (table A1: list of insular and secondarily woody species; table A2: list of ambiguous genera), with reference to the number of secondarily or insular woody species and the total number of species per genus (phylogenetic placement follows the APG III [2009] classification system), the diversity in habit, the habitat of secondarily woody species in and outside the Canary Islands, the presence of protracted juvenilism in wood characters, remarks on the number of habit shifts, and information about insular or secondary woodiness. Table 1 shows that secondarily woody species are present in 46 genera belonging to 18 families; among these, wood development in 34 genera, representing 15 families (fig. 3), did evolve on the Canary Islands, and such species should thus be called insular woody. In the genus Convolvulus, only one of two independent shifts has led to insular woodiness, while the other probably represents secondary woodiness. Table A2 shows that the origin of woodiness in 17 genera cannot be assessed with certainty at this moment. The five families that are represented in table A2 but not in table 1 are Rosaceae, Urticaceae, Plumbaginaceae, Acanthaceae, and Scrophulariaceae; these could potentially be added to the list of families with secondarily (insular) woody species on the Canary Islands. Nevertheless, current evidence rather points to primary woodiness in the genera Gesnouinia and Forsskaolea (both Urticaceae) and in Gymnocarpos, Paronychia, and Polycarpaea (all Caryophyllaceae), so these should probably be discarded, but more data are needed to confirm this.

Figure 2 and table 1 show that most of the insular and secondarily woody genera from which the wood anatomy is known are characterized by multiseriate rays with mainly square to upright ray cells and by flat to continuously decreasing length-on-age curves for vessel elements. Sometimes, scalariform intervessel pitting with wide apertures or multiseriate rays with exclusively upright cells are also observed. Occasionally, rays are absent. However, the studied wood sample of Pterocephalus does not show protracted juvenilism in its wood. In table A2, the same picture arises: mainly square to upright ray cells in most species but no wood features with protracted juvenilism in Marcetella moquiniana.

Figure 3 shows a phylogenetic overview of the 34 insular woody angiosperm genera, based on table 1 . Insular (and secondary) woodiness on the Canary Islands is mostly confined to the euasterid clades, especially in the Lamiales and Asterales. In the rosids, only three families contain insular woody species: Brassicaceae (five genera, although the closest relatives of Parolina remain incompletely known), Fabaceae (Lotus and Ononis), and Malvaceae (Navaea). Outside rosids and asterids, the genus Aeonium is the only group that has evolved into insular woody species. 

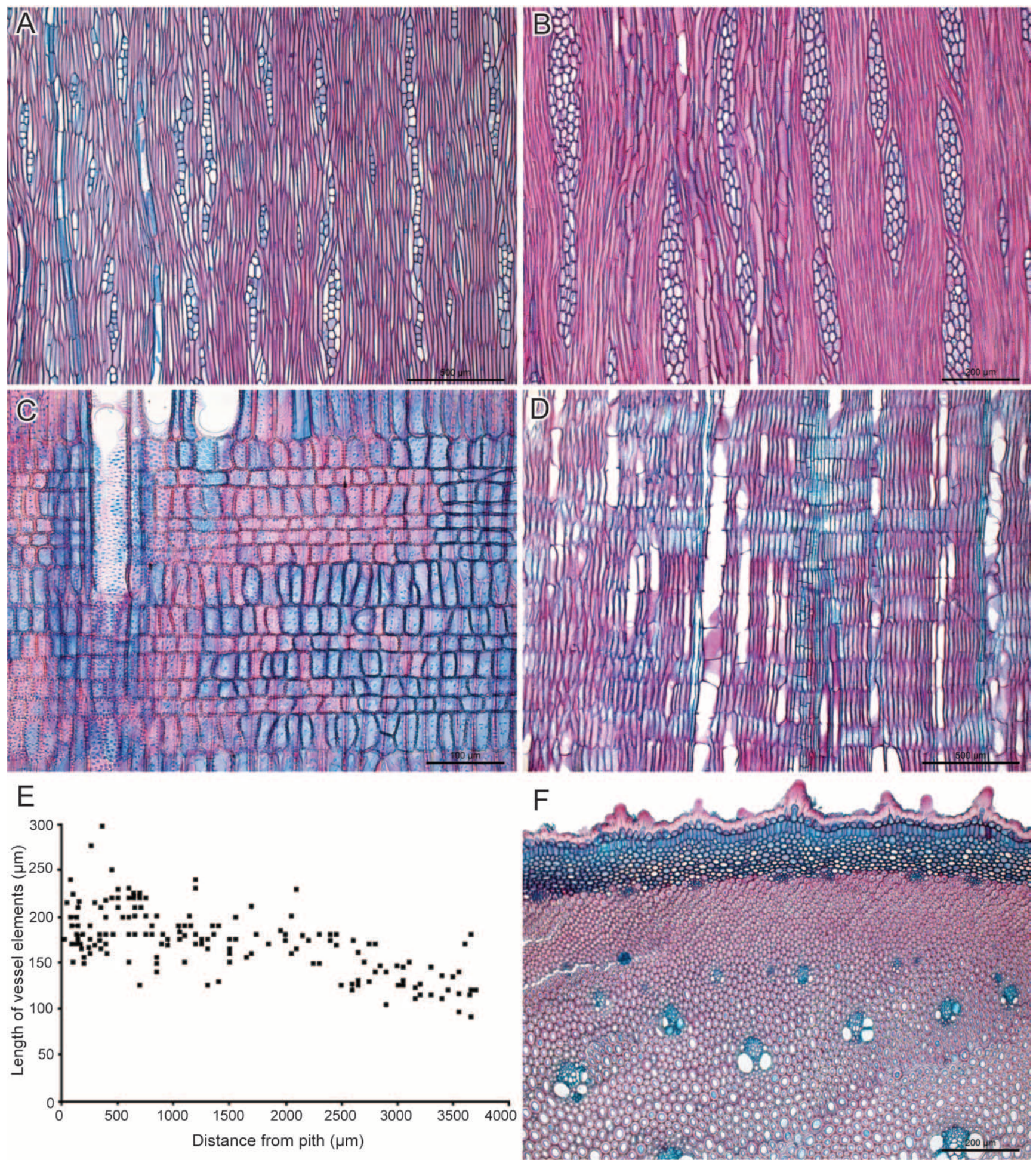

Fig. 2 Wood anatomy of native Canary Island species, showing LM pictures of protracted juvenilism in wood features of truly insular woody species $(A-D)$, a length-on-age curve for vessel elements $(E)$, and an LM section of a "woody" monocot, Asparagus scoparius, without cambium formation $(F)$. A, Rumex lunaria, tangential section, illustrating mainly upright ray cells. $B$, Argyranthemum adauctum, tangential section, showing mainly upright ray cells. C, Echium leucophaeum, radial section, showing mixed square and upright ray cells. D, Lobularia canariensis, radial section, with vague rays consisting of upright cells only. E, Campylanthus salsoloides, decreasing length-on-age curve for vessel elements. F, Asparagus umbellatus, cross section through outer stem part of "woody" monocot stem without cambium activity. 
Table 1

Canary Island (Cl) Genera That Include Woody Species That Have Evolved from Herbaceous Ancestors, with Reference to Their Systematic Position within Angiosperms, Species Composition, Habit, Habitat, Paedomorphic Wood Anatomical Features, Number of Shifts toward (Insular or Secondary) Woodiness, and References Used

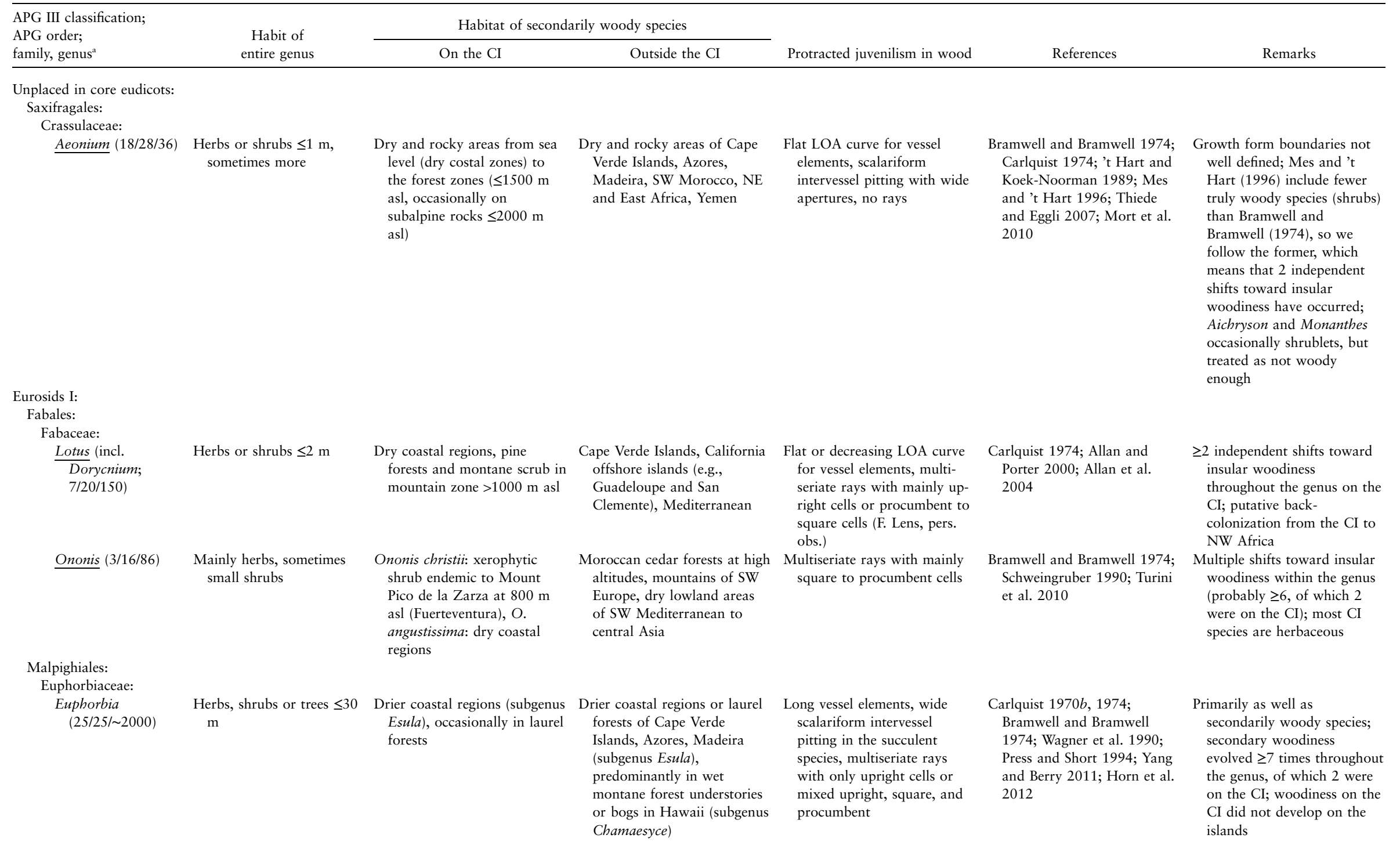


Table 1

(Continued)

\begin{tabular}{|c|c|c|c|c|c|c|}
\hline \multirow{2}{*}{$\begin{array}{l}\text { APG III classification; } \\
\text { APG order; } \\
\text { family, genus }^{\mathrm{a}}\end{array}$} & \multirow{2}{*}{$\begin{array}{l}\text { Habit of } \\
\text { entire genus }\end{array}$} & \multicolumn{2}{|c|}{ Habitat of secondarily woody species } & \multirow[b]{2}{*}{ Protracted juvenilism in wood } & \multirow[b]{2}{*}{ References } & \multirow[b]{2}{*}{ Remarks } \\
\hline & & On the CI & Outside the CI & & & \\
\hline Eurosids II: & & & & & & \\
\hline \\
\hline$\underline{\text { Brassica }}(1 / 3 / \sim 40)$ & $\begin{array}{l}\text { Mostly herbs, occasionally } \\
\text { shrubs (B. oleracea) }\end{array}$ & $\begin{array}{l}\text { B. oleracea (walking-stick } \\
\text { cabbage): irrigated gardens } \\
\text { of the dry lowland areas and } \\
\text { more humid zones }\end{array}$ & $\begin{array}{l}\text { Comparable situation in } \\
\text { Channel Islands, } \\
\text { Mediterranean region }\end{array}$ & $\begin{array}{l}\text { Flat LOA curve for vessel } \\
\text { elements, multiseriate rays } \\
\text { with procumbent to square } \\
\text { ray cells (F. Lens, pers. obs.) }\end{array}$ & $\begin{array}{l}\text { Kowal and Cutler 1974; Appel } \\
\text { and Al-Shehbaz 2003; } \\
\text { Warwick and Sauder 2005; } \\
\text { Franzke et al. 2009; } \\
\text { Warwick et al. } 2010\end{array}$ & $\begin{array}{l}\text { Local inhabitants of the CI } \\
\text { imported seeds of } B \text {. } \\
\text { oleracea } \sim 2000-3000 \mathrm{yr} \\
\text { ago, resulting in the } \\
\text { walking-stick phenotype }\end{array}$ \\
\hline Crambe $(13 / 13 / 41)$ & Herbs or shrubs $\leq 2 \mathrm{~m}$ & $\begin{array}{l}\text { Humid laurel forest, pine } \\
\text { forest or dry lowland scrub }\end{array}$ & $\begin{array}{l}\text { Madeira: in ravines, rocks, and } \\
\text { cliffs, mainly in the western } \\
\text { part usually near the coast } \\
\leq 100 \mathrm{~m} \text { asl }\end{array}$ & $\begin{array}{l}\text { Multiseriate rays with mainly } \\
\text { upright and square cells }\end{array}$ & $\begin{array}{l}\text { Carlquist 1971, 1974; } \\
\text { Bramwell and Bramwell } \\
\text { 1974; Press and Short 1994; } \\
\text { Francisco-Ortega et al. } \\
\text { 1999, } 2002\end{array}$ & $\begin{array}{l}\text { Woodier species (e.g., C. } \\
\text { arborea) grow in dryer } \\
\text { lowland habitat, less-woody } \\
\text { species in the laurel forests } \\
\text { (e.g., C. strigosa) }\end{array}$ \\
\hline Descurainia (7/7/45) & Herbs or shrubs $\leq 1 \mathrm{~m}$ & $\begin{array}{l}\text { Lowland scrub, pine forest, } \\
\text { high-altitude desert } \\
\text { ecological zones }>2000 \mathrm{~m} \\
\text { asl }\end{array}$ & Not applicable & $\begin{array}{l}\text { Multiseriate rays with mainly } \\
\text { upright and square cells }\end{array}$ & $\begin{array}{l}\text { Carlquist 1971, 1974; } \\
\text { Bramwell and Bramwell } \\
\text { 1974; Goodson et al. 2006; } \\
\text { Franzke et al. } 2009\end{array}$ & $\begin{array}{l}\text { Closest relative of insular } \\
\text { woody Descurainia clade is } \\
\text { D. tanacetifolia, including } \\
\text { D. tanacetifolia ssp. } \\
\text { suffruticosa, which is a } \\
\text { "woody herb" with only a } \\
\text { woody basal stem part; since } \\
\text { we do not consider this } \\
\text { species a truly woody } \\
\text { species, Descurainia can be } \\
\text { considered an example of } \\
\text { insular woodiness }\end{array}$ \\
\hline $\begin{array}{l}\text { Erysimum } \\
\qquad(3 / 3 / \sim 180)\end{array}$ & Herbs or shrubs $\leq 2 \mathrm{~m}$ & $\begin{array}{l}\text { Lower and forest zones } \leq 1000 \\
\text { m asl, high-altitude zone } \\
1500-2200 \mathrm{~m} \text { asl }\end{array}$ & $\begin{array}{l}\text { Madeira (rocks, laurel forests), } \\
\text { NW Africa, California } \\
\text { offshore islands (e.g., } \\
\text { Guadeloupe and San } \\
\text { Clemente) }\end{array}$ & $\begin{array}{l}\text { Multiseriate rays with mainly } \\
\text { upright and square cells (F. } \\
\text { Lens, pers. obs.) }\end{array}$ & $\begin{array}{l}\text { Carlquist 1971, 1974; } \\
\text { Bramwell and Bramwell } \\
\text { 1974; Press and Short 1994; } \\
\text { Warwick et al. } 2010\end{array}$ & $\begin{array}{l}\text { Woodiness not evolved on the } \\
\text { CI }\end{array}$ \\
\hline Lobularia $(1 / 3 / 4)$ & $\begin{array}{l}\text { Herbs or shrubs } \leq 0.7 \mathrm{~m} \\
\text { (L. canariensis ssp. } \\
\text { fruticosa) }\end{array}$ & $\begin{array}{l}\text { L. canariensis ssp. palmensis: } \\
\text { in and below forest zones, } \\
\text { on cliffs at } 500-1600 \mathrm{~m} \text { asl; } \\
\text { most subspecies of } L \text {. } \\
\text { canariensis grow in the } \\
\text { xerophytic zone } 0-600 \mathrm{~m} \text { asl }\end{array}$ & $\begin{array}{l}\text { Woodiest taxon } L \text {. canariensis } \\
\text { ssp. fruticosa: steep cliffs } \\
\text { and gravelly slopes of Cape } \\
\text { Verde Islands, sometimes in } \\
\text { dry coastal zone but more } \\
\text { often in more mesic } \\
\text { montane conditions, 200- } \\
1250 \mathrm{~m} \text { asl }\end{array}$ & $\begin{array}{l}\text { Rays very vaguely present, } \\
\text { consisting of few upright ray } \\
\text { cells (F. Lens, pers. obs.) }\end{array}$ & $\begin{array}{l}\text { Borgen 1987; Appel and Al- } \\
\text { Shehbaz 2003; Beilstein et } \\
\text { al. } 2008\end{array}$ & $\begin{array}{l}\text { Most drought-tolerant species } \\
\text { in the genus are the annuals } \\
\text { L. arabica and L. libyca } \\
\text { growing in deserts or } \\
\text { xerophytic seashore } \\
\text { communities outside the CI }\end{array}$ \\
\hline Parolinia $(6 / 6 / 6)$ & Shrubs $\leq 4 \mathrm{~m}$ & $\begin{array}{l}\text { Dry sunny slopes } 100-500 \mathrm{~m} \\
\text { asl }\end{array}$ & Not applicable & $\begin{array}{l}\text { Multiseriate rays with mainly } \\
\text { square to procumbent cells }\end{array}$ & $\begin{array}{l}\text { Bramwell 1970; Carlquist } \\
\text { 1971, 1974; Bramwell and } \\
\text { Bramwell 1974; Khosravi et } \\
\text { al. } 2009\end{array}$ & $\begin{array}{l}\text { Relatives are not yet } \\
\text { discovered, but likely woody } \\
\text { Diceratella, herbaceous } \\
\text { Anastacia, or herbaceous } \\
\text { Morettia are good } \\
\text { candidates; still some doubt } \\
\text { about insular or secondary } \\
\text { woodiness }\end{array}$ \\
\hline
\end{tabular}


Resedaceae:

Reseda (incl.
Oligomeris

Randonia,

Ochradenus

$1 / 5 / \sim 77)$

Malvales:

Malvaceae:

Lavatera (1/3/18) Herbs or shrubs Dry lowland scrub, open areas
at borders of laurel forest

\section{Mexico, Ethiopia, wester}

Northern slopes of the oldest Not applicable parts of the island Tenerife, lowland regions

Sister to asterids:

Caryophyllales:

Amaranthaceae:

Bassia (incl. Cheno- Herbs or small shrubs leoides; $1 / 1 / 21$ )

Traganum (1/1/2) Small shrubs $\leq 1 \mathrm{~m}$

Caryophyllaceae:

Silene $(1 / 26 / \sim 700)$

Dry beach vegetation

Dry lowland regions Australia Middle East and West

Pakistan, Socotra, western

South Arabian Peninsula,

Socotra Islands

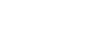

Desert shrubs from the SE Mediterranean region to the

\section{Dry regions in western Mediterranean to East Asia \\ ltiseriate rays with mainly upright cells} and Asia

Coastal salty soils or desert throughout the world

Sea coasts and inland saline soils throughout the world

Multiseriate rays with mainly upright cells

?
Multiseriate rays with mainly
upright cells or rays absent

Scott 1977; Wilson 1980; 2006

Hopkins and Blackwell 1977; Schweingruber 1990; Kühn
Dry regions in northern Africa

Dry and salty coastal regions small shrubs
Sand dunes, coastal regions

Drier parts in northern Africa, Raylessness eastern Mediterranean

Open and dry alpine vegetation on Hawaiia Islands $\leq 3500 \mathrm{~m}$ asl pine forests
Multiseriate rays with mainly upright and square cells$$
\text { Bram }
$$

Bramwell and Bramwell 1974;
Carlquist 1998b; Kubitzki 2003; Martín-Bravo et al. 2007

Multiseriate rays consisting of mixed upright, square, and procumbent body ray cells Kühn 1993; Kadereit et al. 1993; Schütze et al. 2003; Heklau et al. 2012

Bramwell and Bramwell 1974; Kühn 1993; Akhani et al. 2007; Heklau et al. 2012

Multiseriate rays with upright ray cells or raylessness

Bramwell and Bramwell 1974; Carlquist 1974, 1995;
4 independent colonizations to the $\mathrm{CI}$ in the genus, of which 2 resulted in secondary woodiness; the secondarily woody CI species (R. scoparius and Oligomeris linifolia) have woody relatives

\section{Highly polyphyletic; CI species} L. acerifolia is sister to woody L. maritima, so no truly insular woody species; secondary woodiness developed $\geq 3$ times

Bramwell and Bramwell 1974; N. phoenicea is placed basal to $N$. phoenicea is placed
the Lavatera-Malva the Lavatera-Malva
complex, so possibly insular woody relict taxon

Woodiness not evolved on the CI. sister species Cl, sister species of B. tomentosa is also woody and grows from Morocco to Ira $\geq 2$ independent colonizations toward the CI; woodiness not evolved on the CI; all the woody species also occur on the continent; successive cambia present

Woodiness not evolved on the CI; all the woody species also occur on the continent $\geq 3$ independent colonizations toward the CI; woodiness not evolved on the CI; all the woody species also occur on the continent; successive cambia present

Close relatives are secondarily woody continental species, so Traganum is not truly insular woody

Probably $\geq 2$ independent shifts to insular woodiness in the genus, of which 1 was on the CI, but phylogeny is too 1993; Eggens et al. 2007; Harbaugh et al. 2010; Greenberg and Donoghue poorly resolved 
Table 1

(Continued)

\begin{tabular}{|c|c|c|c|}
\hline \multirow{2}{*}{$\begin{array}{l}\text { APG III classification; } \\
\text { APG order; } \\
\text { family, genus }\end{array}$} & \multirow{2}{*}{$\begin{array}{l}\text { Habit of } \\
\text { entire genus }\end{array}$} & \multicolumn{2}{|c|}{ Habitat of secondarily woody species } \\
\hline & & On the CI & Outside the CI \\
\hline $\begin{array}{l}\text { Polygonaceae: } \\
\text { Rumex (1/5/ 200) }\end{array}$ & $\begin{array}{l}\text { Mostly herbs, rarely shrubs } \\
\leq 2 \mathrm{~m} \text { or vines } \leq 12 \mathrm{~m}\end{array}$ & $\begin{array}{l}\text { Dry coastal regions and } \\
\text { midelevation scrub }\end{array}$ & $\begin{array}{l}\text { Hawaiian Islands (variable: } \\
\text { mesic to wet forest and } \\
\text { subalpine woodland } 660- \\
3050 \mathrm{~m} \text { asl), China (dry } \\
\text { mountain slopes at } 600- \\
3200 \mathrm{~m} \text { asl) }\end{array}$ \\
\hline
\end{tabular}

Euasterids I:

Gentianales:

Gentianaceae:

References

Remarks

Multiseriate rays with a mix of Bramwell and Bramwell 1974; 1 shift toward insular procumbent, square, and Carlquist 1974, 2003a; upright cells Brandbyge 1993; Wagner et al. 1990; Anjen et al. 2003; Sanchez and Kron 2008; Sanchez et al. 2009; Burke et al. 2010 woodiness

Suffrutescent herbs to

small shrubs $\leq 2 \mathrm{~m}$

Moist laurel forest habitat

\section{Rubiaceae:}

Rubia $(1 / 2 / \sim 80)$

Lamiales:

Lamiaceae:

Lavandula $(5 / 5 / \sim 36)$ Herbs or shrubs

Mostly herbs, occasionally shrubs (R. fruticosa)

R. fruticosa: very common throughout the dry lowe zones

$\frac{\text { Micromeria }}{(15 / 15 / \sim 70)} \quad$ Herbs or shrubs

Salvia $(4 / 4 / \sim 900)$

Herbs and shrubs $\leq 2 \mathrm{~m}$, sometimes more

Herbs or shrubs

Sideritis

(24/24/ 148)
Commonly in dry coastal regions $\leq 600 \mathrm{~m}$ asl or in pine forests $\leq 1600 \mathrm{~m}$ as

Cape Verde Islands

\section{Mainly in dry to medium-dry lowland habitats, \\ occasionally in pine forests} ecological zone

Commonly found in the dry lower zones, occasionally in lower zonc

Islands coastal region to more humid montane and pine forests $\leq 2100 \mathrm{~m}$ asl, humid laurel forests
Not applicable

\section{Wood rayless in earlier portion, rays relatively upright cells}

High-elevation semideserts an steppes in central Asia, often $1000-3000 \mathrm{~m}$ as

Flat LOA curve for vesse elements, raylessness

Bramwell and Bramwell 1974;

Bramwell and Bramwell 1974. Temesy 2005; Bremer and

$\begin{array}{cc}\text { Mainly upright to square cells } & \begin{array}{c}\text { Bramwell and Bramwell 1974; } \\ \text { in multiseriate rays }\end{array} \\ & \text { Carlquist 1992a; Upson and } \\ \text { Andrews 2004 }\end{array}$

Rays vaguely present, uniseriate with few upright cells

Bramwell and Bramwell 1974;

Similar dry habitats in Madeira and Cape Verde

Equatorial uplands of Africa (SW, NW, and NE of Africa, Madagascar, Somalia) and South America, SW US

Mainly upright to square cells in multiseriate rays

ry or exposed habitats in Madeira
Mainly upright to square cells in multiseriate rays Press and Short 1994; Carlquist 1974, 1984; Thiv et al. 1999; Struwe et al. 2002; Thiv and Kadereit 2002; Mansion and Struwe 2004 Koek-Noorman 1976;

Ehrendorfer and SchönbeckEriksson 2009 Carlquist 1992a; Upson and Andrews 2004

chweingruber 1990;

Meimberg et al. 2006;

Bräuchler et al. 2010

Most individuals growing in the wild can be considered woody herbs, but others are woodier

Herbaceous R. angustifolia grows in much more humid conditions (e.g., laurel forests)

Probably primary woodiness (subgenera Subaudia and Lavandula) as well as insular woodiness (subgenus Fabricia) Fabricia)
1 shift toward insular woodiness

pling 1938; Bramwell and Bramwell 1974; Carlquist 1974, 1992a; Hedge 1974; Walker et al. 2004

Several independent shifts toward insular woodiness within the genus, of which probably 1 was on the $\mathrm{C}$ Bramwell and Bramwell 1974; 1 shift toward insular Bendiksby et al. 2011 
Plantaginaceae:
Campylanthus

$\frac{1}{(1 / 1 / 12)}$

Shrubs $\leq 2 \mathrm{~m}$

Digitalis (incl.

Isoplexis; 3/3/23)

Herbs and shrubs $\leq 2 \mathrm{~m}$

Globularia (incl.

Herbs and (sub)shrubs $\leq 2$

Lytanthus; 3/3/23) m (G. salicina)

Kickxia (1/5/9)

Herbs or small shrubs

Rosette herbs, (sub)shrubs $\leq 2 \mathrm{~m}$, miniature trees $\leq 1$ $\mathrm{m}$

$\frac{\text { Plantago }}{(3 / 14 / \sim 250)}$$$
\mathrm{n}
$$

places in forest rocky

below, rocky places from

lower zone to the

mountains, high-altitude

mountains $\leq 1800 \mathrm{~m}$ asl

among rocks and boulders

Solanales:

Convolvulaceae:

$\frac{\text { Convolvulus }}{(11 / 14 / \sim 200)}$

Herbs, shrubs, trees, or lianas $\leq 4 \mathrm{~m}$

Dry coastal zone, laurel forests, often on rocks or cliffs

Madeira (mainly in humid gullies and ravines among rocks), Selvagems,

Mediterranean

Dry regions of northern Africa, eastern Mediterranean,

southwestern Asia

Hawaiian Islands (P. princeps: rain forests, mesic forests, Islands, South America and Africa (equatorial uplands), St. Helena

\section{Unplaced:}

Boraginaceae:

Echium $(19 / 25 / 60)$

Shrubs $\leq 3 \mathrm{~m}$, rosette trees $\leq 4 \mathrm{~m}$

Dry coastal rocky regions, cliffs, semidesert habitats, desert ecological zone

Islands, Madeir (sea cliffs and dry rocky forests)

procumbent, square, and upright cells or with mainly upright ray cells

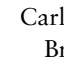
1974; Press and Short 1994; Böhle et al. 1996; GarcíaMaroto et al. 2009

B. salicifolium: scattered in dry, rocky places throughou the mountains of Madeira, generally $>1000 \mathrm{~m}$ asl

Bramwell and Bramwell 1974, Fischer 2004; Albach et al. 2005

Bramwell and Bramwell 1974; Carlquist 1974; Press and Short 1994; Bräuchler et al. 2004; Albach et al. 2005

Bramwell and Bramwell 1974 Carlquist 1974, 1992b;

Bramwell and Bramwell 1974; Ghebrehiwet 2001; Fische Carlquist 1970c, 1974, 1992 Bramwell and Bramwell 1974; Wagner et al. 1990; Rønsted et al. 2002; Albach et al. 2005; Dunbar-Co et al. 2008

Sa'ad 1967; Bramwell and Bramwell 1974; Carlquist 1974; Carlquist and Hanson 1991; Press and Short 1994; Carine et al. 2004

Mostly herbs, occasionally
shrubs (e.g., $B$. salicifolium) zone $\leq 10$
region

Bramwell and Bramwell 1974; Cannon 1994; Neves and Watson 2004
1 shift toward insular woodiness on the $\mathrm{CI}$

1 shift toward insular woodiness

1 shift toward insular woodiness

1 shift toward insular woodiness on the $\mathrm{Cl}$

Several independent shifts toward insular woodiness within the genus; on the $\mathrm{CI}$, 3 colonizations, of which $\geq 1$ resulted in insular woodiness; putative backcolonization from the $\mathrm{CI}$ to NW Africa

2 independent shifts toward the CI leading to secondary woodiness; insular woodiness in C. caput-medusae, C. scoparius, C. floridus is doubtful because of close relationship with woody continental C. dorycnium; also back-colonization toward continent

1 major shift toward insular woodiness, 3 reversals back to secondary herbaceousness

B. fruticosum is primarily woody, from molecular data and wood anatomy; putative back-colonization from the CI to NW Africa 
Table 1

(Continued)

\begin{tabular}{|c|c|c|c|c|c|c|}
\hline \multirow{2}{*}{$\begin{array}{l}\text { APG III classification; } \\
\text { APG order; } \\
\text { family, genus }^{\mathrm{a}}\end{array}$} & \multirow{2}{*}{$\begin{array}{l}\text { Habit of } \\
\text { entire genus }\end{array}$} & \multicolumn{2}{|c|}{ Habitat of secondarily woody species } & \multirow[b]{2}{*}{ Protracted juvenilism in wood } & \multirow[b]{2}{*}{ References } & \multirow[b]{2}{*}{ Remarks } \\
\hline & & On the CI & Outside the CI & & & \\
\hline \multicolumn{7}{|l|}{ Asterales: } \\
\hline \multicolumn{7}{|l|}{ Asteraceae: } \\
\hline$\frac{\text { Argyranthemum }}{(19 / 19 / 23)}$ & Shrubs $\leq 1.5 \mathrm{~m}$ & $\begin{array}{l}\text { Dry coastal regions, pine } \\
\text { forests, laurel forests, high- } \\
\text { altitude desert zone } 1900- \\
2200 \mathrm{~m} \text { asl }\end{array}$ & $\begin{array}{l}\text { Mainly on wet coastal cliffs, } \\
\text { Madeira }\end{array}$ & $\begin{array}{l}\text { Multiseriate rays with mainly } \\
\text { upright and square cells (F. } \\
\text { Lens, pers. obs.) }\end{array}$ & $\begin{array}{l}\text { Bramwell and Bramwell 1974; } \\
\text { Press and Short 1994; } \\
\text { Francisco-Ortega et al. } \\
\text { 1997; Anderberg et al. 2007; } \\
\text { Oberprieler et al. } 2009\end{array}$ & $\begin{array}{l}1 \text { shift toward insular } \\
\text { woodiness }\end{array}$ \\
\hline Asteriscus $(4 / 5 / 8)$ & Herbs or shrubs $\leq 0.7 \mathrm{~m}$ & $\begin{array}{l}\text { Dry coastal zones, semiarid } \\
\text { mountain slopes, or laurel } \\
\text { forests }\end{array}$ & $\begin{array}{l}\text { Cape Verde (arid slopes), } \\
\text { Moroccan desert }\end{array}$ & $?$ & $\begin{array}{l}\text { Bramwell and Bramwell 1974; } \\
\text { Halvorsen and Borgen 1986; } \\
\text { Francisco-Ortega et al. } \\
\text { 2001b; Goertzen et al. 2002; } \\
\text { Anderberg et al. 2007; } \\
\text { Anderberg } 2009\end{array}$ & $\begin{array}{l}2 \text { independent shifts toward } \\
\text { insular woodiness; woody } \\
\text { shrubs taller in laurel forests }\end{array}$ \\
\hline Atractylis $(3 / 3 / 30)$ & Herbs or small shrubs & Rocky coasts near the sea & Not applicable & $?$ & $\begin{array}{l}\text { Bramwell and Bramwell 1974; } \\
\text { Anderberg et al. 2007; } \\
\text { Susanna and Garcia-Jacas } \\
2009\end{array}$ & $\begin{array}{l}1 \text { shift toward insular } \\
\text { woodiness }\end{array}$ \\
\hline $\begin{array}{l}\frac{\text { Bethencourtia }}{\text { (segregated from }} \\
\text { Senecio; } 3 / 3 / 3 \text { ) }\end{array}$ & Shrubs $\leq 1 \mathrm{~m}$ & $\begin{array}{l}\text { Dry midelevation rocks, } \\
\text { borders of laurel forests, } \\
\text { high-altitude desert zone } \\
\sim 2000 \mathrm{~m} \text { asl }\end{array}$ & Not applicable & ? & $\begin{array}{l}\text { Bramwell and Bramwell 1974; } \\
\text { Anderberg et al. 2007; Pelser } \\
\text { et al. 2007, 2010a; } \\
\text { Nordenstam et al. } 2009\end{array}$ & $\begin{array}{l}1 \text { shift toward insular } \\
\text { woodiness }\end{array}$ \\
\hline Carlina $(5 / 5 / 28)$ & $\begin{array}{l}\text { Herbs, shrubs, or treelets } \\
\leq 3 \mathrm{~m}\end{array}$ & $\begin{array}{l}\text { High-altitude desert zone } \\
1900-2100 \mathrm{~m} \text { asl, dry cliffs } \\
\text { in dry lower zone } 150-600 \\
\mathrm{~m} \text { asl, cliffs and rocks in } \\
\text { lower zone }\end{array}$ & SE Aegean Islands & $\begin{array}{l}\text { Multiseriate rays with upright } \\
\text { to square cells (F. Lens, pers. } \\
\text { obs.) }\end{array}$ & $\begin{array}{l}\text { Bramwell and Bramwell 1974; } \\
\text { Carlquist 1974; Anderberg } \\
\text { et al. 2007; Susanna and } \\
\text { Garcia-Jacas 2009; } \\
\text { Wahrmund et al. } 2010\end{array}$ & $\begin{array}{l}1 \text { shift toward insular } \\
\text { woodiness on the CI }\end{array}$ \\
\hline $\begin{array}{c}\text { Cheirolophus } \\
(16 / 16 / 25)\end{array}$ & Shrubs $\leq 3 \mathrm{~m}$ & $\begin{array}{l}\text { Often in dry coastal region on } \\
\text { cliffs, occasionally in high- } \\
\text { altitude desert zone } 2000- \\
2200 \mathrm{~m} \text { asl }\end{array}$ & $\begin{array}{l}\text { Western Mediterranean, } \\
\text { northern Africa, and } \\
\text { Macaronesia }\end{array}$ & $\begin{array}{l}\text { Multiseriate rays with upright } \\
\text { to square cells (F. Lens, pers. } \\
\text { obs.) }\end{array}$ & $\begin{array}{l}\text { Bramwell and Bramwell 1974; } \\
\text { Susanna et al. 1999; } \\
\text { Anderberg et al. 2007; } \\
\text { Susanna and Garcia-Jacas } \\
2009\end{array}$ & $\begin{array}{l}\text { Macaronesian group } \\
\text { monophyletic but with } \\
\text { woody ancestors }\end{array}$ \\
\hline $\begin{array}{l}\text { Kleinia (segregated } \\
\text { from Senecio; } \\
1 / 1 / \sim 50 \text { ) }\end{array}$ & $\begin{array}{l}\text { (Succulent) herbs or } \\
\text { (succulent) shrubs } \leq 2 \mathrm{~m}\end{array}$ & $\begin{array}{l}\text { Very common in the dry lower } \\
\text { zone }\end{array}$ & $\begin{array}{l}\text { Africa, Madagascar, Arabia, } \\
\text { east to India and Sri Lanka, } \\
\text { often in dry areas }\end{array}$ & $\begin{array}{l}\text { Multiseriate rays with upright } \\
\text { to square cells (F. Lens, pers. } \\
\text { obs.) }\end{array}$ & $\begin{array}{l}\text { Bramwell and Bramwell 1974; } \\
\text { Carlquist 1974; Pelser et al. } \\
\text { 2007, 2010a; Nordenstam et } \\
\text { al. } 2009\end{array}$ & $\begin{array}{l}\text { Also many woody species } \\
\text { outside the CI, so woodiness } \\
\text { probably did not evolve on } \\
\text { the CI }\end{array}$ \\
\hline Launaea $(1 / 4 / 54)$ & $\begin{array}{l}\text { Herbs or (rosette) shrubs } \\
\leq 2 \mathrm{~m}\end{array}$ & $\begin{array}{l}\text { Extremely dry coastal regions, } \\
\text { especially on the southern } \\
\text { slopes, } \leq 700 \mathrm{~m} \text { asl }\end{array}$ & $\begin{array}{l}\text { Dry regions (often semidesert } \\
\text { areas) of Mediterranean } \\
\text { region (incl. Balearic } \\
\text { Islands), Atlas Mountains } \\
\text { (NW Africa), Saharo- } \\
\text { Arabian region, Irano- } \\
\text { Turanian region, India }\end{array}$ & $\begin{array}{l}\text { Multiseriate rays with mainly } \\
\text { upright to square cells (F. } \\
\text { Lens, pers. obs.) }\end{array}$ & $\begin{array}{l}\text { Bramwell and Bramwell 1974; } \\
\text { Kilian 1997; Anderberg et } \\
\text { al. 2007; Kilian et al. } 2009\end{array}$ & $\begin{array}{l}\text { Woodier species occur in much } \\
\text { more arid environments; } \\
\text { woody species not confined } \\
\text { to islands, so it might be } \\
\text { that woodiness did not } \\
\text { evolve on the CI }\end{array}$ \\
\hline
\end{tabular}


Sonchus

$(25 / 33 / \sim 92)^{\mathrm{b}}$

Herbs, (rosette) shrubs, or trees $\leq 5 \mathrm{~m}$

Gonospermum (incl. Shrubs $\leq 4 \mathrm{~m}$ Lugoa; 6/7/7
Mainly on coastal cliffs and lower dry zones, also in

more humid forest (pine and

laurel) zones

Lower zones and laurel fores ones on cliffs, $100-1000$ asl
Laurel forests of Madeira

, Madeir (coastal cliffs and rocks, wet ravines $800-1200 \mathrm{~m}$ asl),

Juan Fernandez Islands, San Ambrosio Islands

Not applicable

(n)
Coastal rocks, in mountain areas and upper forest zone $\leq 1900 \mathrm{~m}$ asl, high-altitude desert zone 2000-2200 m

Irano-Oriental region, Mediterranean,

Macaronesia, eastern Africa, and central Asia
Bramwell and Bramwell 1974; $\geq 2$ independent shifts toward Panero et al. 1999; Anderberg et al. 2007; Pelser et al. 2007, 2010a;

Nordenstam et al. 2009

Flat LOA, relatively long vessel Carlquist 1962, 1974; elements, scalariform Bramwell and Bramwell intervessel pitting with wide apertures, rays with mainly upright cells

Multiseriate rays with mainly upright to square cells (F. Lens, pers. obs. 974; Press and Short 1994; Kim et al. 2007

Bramwell and Bramwell 1974; Carlquist 1974; FranciscoOrtega et al. 2001a; Anderberg et al. 2007; Oberprieler et al. 2009

Bramwell and Bramwell 1974; Carlquist 1982; Press and Short 1994; Carlson et al. 2009

1 shift toward insular or secondary woodiness on the CI; still some doubt about insular or secondary woodiness

Note. APG = Angiosperm Phylogeny Group; LOA curve = length-on-age curve; pers. obs. = personal observation.

${ }^{a}$ The three numbers in parentheses are the number of native secondarily woody species on the CI, the number of CI species, and the total number of species. Insular woody genera are underlined.

b Includes Atalanthus, Babcockia, Chrysoprenanthes, Dendroseris, Lactucosonchus, Sventenia, and Thamnoseris, among others. 


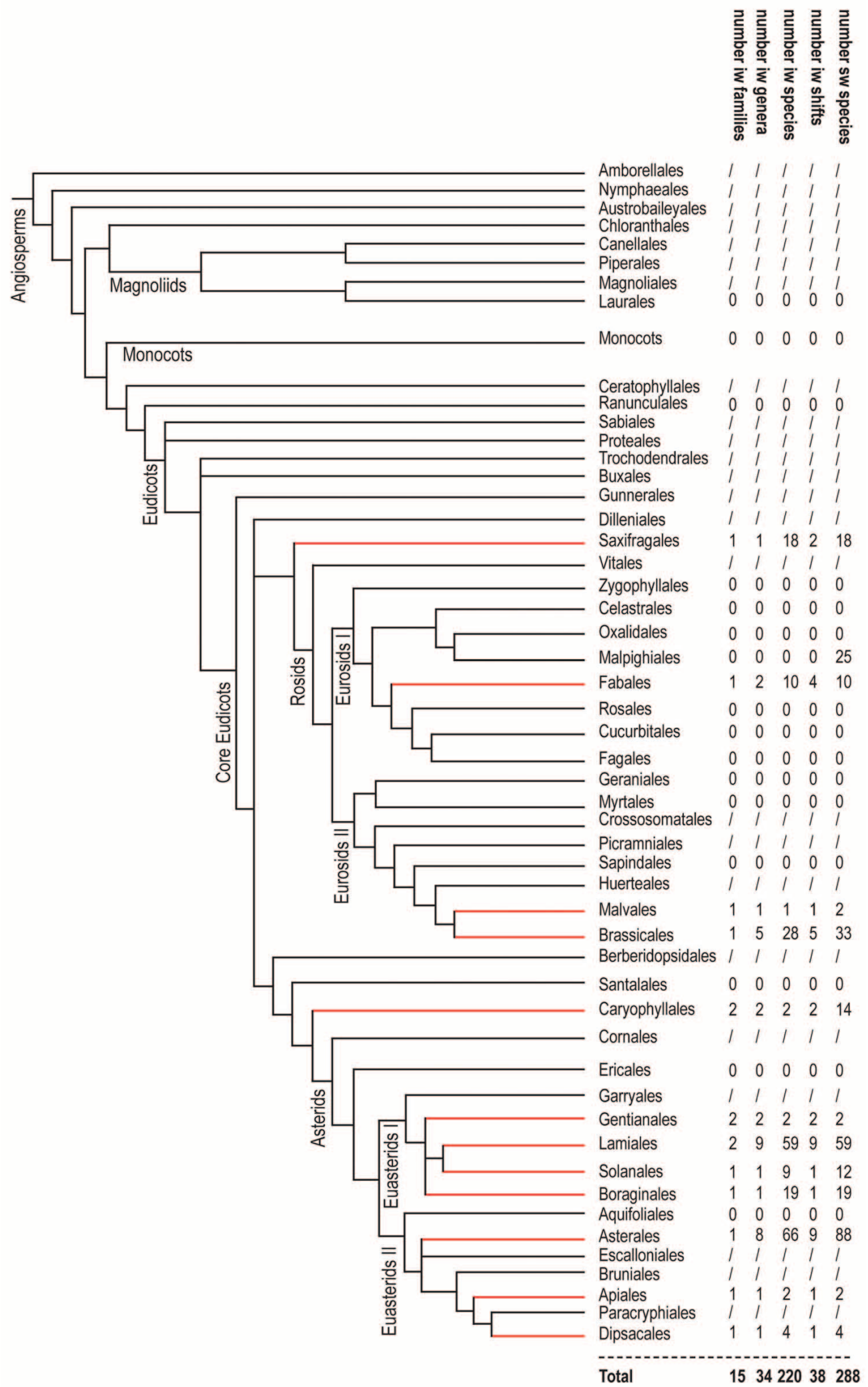

Fig. 3 APG III (2009) phylogeny showing all ordinal lineages including truly insular woody species (red branches) of the Canary Islands with reference to the number of families, genera, species, and shifts. A solidus (/) indicates that there are no native species belonging to this group on the Canary Islands. iw = insular woody; sw = secondarily woody. 
Table 1 also indicates that most of the insular woody species are confined to the dry lower zone of the Canary Islands, although the genera Argyranthemum, Crambe, Echium, Gonospermum, Sideritis, and Sonchus are much more widespread and also occur in pine forests and the much more humid laurel forests. However, when one looks carefully at the distribution of these six insular woody genera within the laurel forests, most of them typically occur in the lower, drier laurel forest parts intermixed with pine forests or in sunny places and rocks within the laurel forests (del Arco et al. 2010). Ixanthus and Digitalis are typical shrubs of the laurel forests, but these shrubs never produce thick, woody stems. A small percentage of the insular woody species-for instance, species of the genera Aeonium, Descurainia, Echium, Micromeria, and Pterocephalus-also occur in the high-altitude desert from 1900 to $2500 \mathrm{~m}$ asl, where frost occurs. Evidently, frost temperatures increase with increasing height, especially during the winter months January and February, but strong frost events below $-6^{\circ} \mathrm{C}$ do not occur (Martín Osorio et al. 2007).

According to the latest land plant checklist of the Canary Islands (Arechavaleta et al. 2010), the current flora contains 1337 native species of flowering plants, of which 1104 are traditional dicots and 234 are monocots (table 2). Within the traditional dicots - the angiosperm lineages that are capable of producing wood by a vascular cambium-it is surprising to see that $59 \%$ of the species are herbaceous (increasing to $66 \%$ within angiosperms as a whole), $26 \%$ are secondarily woody (including $20 \%$ insular woody species), and $11 \%$ are primarily woody; in $4 \%$ of the species, the origin of woodiness remains doubtful. When only the endemic species of traditional dicots are taken into account, the number of herbaceous endemics significantly drops, from $59 \%$ to $34 \%$, while the proportions of secondarily and insular woody species increase drastically (from $26 \%$ to $46 \%$ and from $20 \%$ to $40 \%$, respectively).

\section{Discussion}

\section{Differences in Colonization and Radiation Events among Insular Woody Lineages}

As summarized in table 2 and figure 3, 38 shifts to insular woodiness on the Canary Islands gave rise to 220 truly insular woody species belonging to 34 genera and 15 families, representing a significant proportion of the native traditional dicots $(20 \%)$. Of the 15 largest Canary Island genera with 10 or more endemic species (Whittaker and Fernández-Palacios 2010, p. 229), nine are characterized by insular woody species (Aeonium, Argyranthemum, Convolvulus, Crambe, Echium, Lotus, Micromeria, Sideritis, and Sonchus), in total representing almost $70 \%$ of the insular woody species found. Most of these larger radiations are characterized by a single colonization followed by radiation into several insular woody species, while Aeonium, Convolvulus, and Lotus are characterized by two shifts (table 1). In Asteriscus and Ononis, two independent shifts have led to only a handful of species, while the genera Campylanthus, Ixanthus, Kickxia, Lobularia, Pericallis, Rubia, Rumex, and Silene each harbor only one insular woody species (table 1 ). This demonstrates that radiations within a limited number of insular woody genera (9 out of 34 ) greatly contributed to the Canary Island flora, but the reason for this remains a mystery. Most likely, many more herbaceous colonizers must have reached the Canary Islands from the African continent or the Mediterranean region, leading to potentially even more insular woody species, but not every colonization event resulted in a successful settlement on the island (Whittaker and Fernández-Palacios 2010).

Although colonizations from the mainland toward the $\mathrm{Ca}-$ nary Islands were plentiful, Caujapé-Castells (2011) demonstrated, on the basis of molecular phylogenies, that "biodiversity boomerangs" from the islands toward the mainland have occurred in at least 30 genera, of which six include insular woody species (Aeonium, Bupleurum, Convolvulus, Lotus,

Table 2

Overview of the Life Forms of Native Angiosperms on the Canary Islands

\begin{tabular}{lcc}
\hline & Traditional dicots & Monocots \\
\hline Total number of native angiosperm species & 1104 & 234 \\
Secondarily woody species & $288(26 \%)$ & Not applicable \\
Insular woody species (included in secondarily woody species) & $220(20 \%)$ & Not applicable \\
Primarily woody species & $122(11 \%)$ & Not applicable \\
Herbaceous species & $649(59 \%)$ & $232(99 \%)^{\mathrm{a}}$ \\
Potential secondarily or insular woody species & $45(4 \%)$ & Not applicable \\
Endemic species & $507(46 \%)$ & $25(11 \%)$ \\
Secondarily woody endemic species & $234(46 \%)^{\mathrm{b}}$ & Not applicable \\
Insular woody endemics (included in secondarily woody endemics) & $202(40 \%)^{\mathrm{b}}$ & Not applicable \\
Primarily woody endemics & $64(13 \%)^{\mathrm{b}}$ & Not applicable \\
Herbaceous endemics & $174(34 \%)^{\mathrm{b}}$ & $24(96 \%)^{\mathrm{c}}$ \\
Potential secondarily or insular woody endemics & $35(7 \%)^{\mathrm{b}}$ & Not applicable \\
\hline
\end{tabular}

Note. The proportions of secondarily woody species, insular woody species, primarily woody species, and herbaceous species are compared to the total number of native flowering plants species. Percentages in rows after "Endemic species" are based on the endemic species. Data were compiled on the basis of the checklist of Arechavaleta et al. (2010).

a Two native Dracaena spp. were excluded.

b Percentage is based on the 507 endemic species.

c The exception is Dracaena tamaranae; see "Herbaceousness Prevails in Canary Island Angiosperms" for details. 
Navaea, and Plantago). Consequently, mainland northwest Africa not only is one of the main sources of the present Canary Island flora (ranked second after the Mediterranean region) but is also a substantial historical sink for the archipelago's biodiversity (Caujapé-Castells 2011). This is especially true for the so-called Macaronesian enclave, the coastal region of northwestern mainland Africa between Agadir (Morocco) and Nouadhibou (Mauritania).

\section{Age of Insular Woody Lineages}

Dating estimates of Canary genera with insular woody species are known for only a few genera, such as Aeonium, Convolvulus, Crambe, Echium, Sideritis, and Sonchus (Kim et al. 2008; García-Maroto et al. 2009). These age estimates indicate that the insular woody subgroups evolved $\sim 8.5-8 \mathrm{Ma}$ (Aeonium and Crambe), 5.5 Ma (Sonchus), 3 Ma (Sideritis and Echium; Kim et al. 2008), and 1.5 Ma (Convolvulus; Carine 2005), while García-Maroto et al. (2009) found an older age for the insular woody subgroup of Echium ( $6 \mathrm{Ma})$. Therefore, although information about the evolutionary age of insular woodiness is very incomplete and potentially prone to errors, the available dated phylogenies point to recent radiations as well as older relict insular woody groups. Generally, this agrees with the concept of Vargas (2007), who searched for molecular phylogenies to reveal crown-based lineages (recent clades) versus stem-based lineages (lineage relictualism). According to this concept, four insular woody genera should be considered relicts (Argyranthemum, Crambe, Ixanthus, and Navaea), while seven are regarded as recent clades (Aeonium, Asteriscus, Echium, Gonospermum, Pericallis, Sideritis, and Sonchus). However, at least one crown-based lineage (Aeonium) is much older than some of the stem-based lineages, assuming that not all crown-based groups have to be recent (and vice versa: not all lineage-based groups are by definition relicts).

The younger insular woody lineages are especially interesting to investigate in the light of major paleoclimatic drought events, such as the formation of the Sahara (starting 5-6 Ma; Potts and Behrensmeyer 1992; Schuster et al. 2006) and the onset of cooler and drier periods during the glaciation cycles, co-occurring with lower sea levels (during the past 2-3 Myr; García-Talavera 1997; Geldmacher et al. 2001; Meco et al. 2005, 2006; Fernández-Palacios et al. 2009). If many insular woody groups would have ages of $3 \mathrm{Myr}$ or younger, as demonstrated in some of the large insular woody subclades of Convolvulus (Carine 2005) and Sideritis (Kim et al. 2008), or if some other insular woody groups have radiated in that period (as García-Maroto et al. 2009 demonstrated for Echium), this would provide extra arguments for our new hypothesis linking secondary woodiness with increased drought resistance (see below for more arguments).

\section{Protracted Juvenilism in Wood: Interpret with Caution!}

Table 1 shows that most of the insular and secondarily woody genera are characterized by protracted juvenilism in their wood, which is also confirmed in the genera with an ambiguous origin of woodiness. Decreasing or flat length-onage curves for vessel elements and an abundance of square to upright cells in rays are commonly found (fig. 2), while other forms of paedomorphosis in the Carlquistian sense, such as scalariform intervessel pitting with wide apertures, rays with exclusively upright cells, or raylessness, are scarce (Carlquist 2009 , 2012). Although the value of these wood features for identifying secondarily woody groups has been validated in our study on the basis of independent molecular phylogenies, one should always be careful when interpreting this wood anatomical syndrome. First, "protracted juvenilism" should replace the commonly used term "paedomorphosis" (Carlquist 1962), which actually is incorrect with respect to secondary woodiness because secondarily woody taxa add a woody growth stage on top of the ancestral herbaceous growth stage (i.e., peramorphosis; Olson 2007). Second and more important, there is growing evidence that protracted juvenilism in wood features is related to the specific growth forms, such as rosette trees, stem succulents, or slender-stemmed shrubs, that were investigated by Carlquist (1962) in his pioneering paedomorphosis paper, instead of representing information about the evolutionary origin of woodiness of a particular taxon. This is further emphasized by one of Carlquist's most recent reviews, where he links protracted juvenilism in wood with sympodial growth forms that are characteristic in earlydiverging, (primarily) woody angiosperms (Carlquist 2009). Independent molecular phylogenies show that many more primarily woody taxa with growth forms comparable to the ones commonly found in secondarily woody taxa also exhibit, for example, rays with mainly upright cells, such as those in the ericaceous dwarf shrubs Cassiope, Corema, and Empetrum (Carlquist 1989), the pachycaul rosette trees in the epacrids clade of Ericaceae (Lens et al. 2003), and the Moringa bottle trees (Olson and Carlquist 2001). The same is true for the tall, primarily woody stem succulents in the family Didiereaceae (e.g., Alluaudia, Decarya, and Didierea) that are derived from the smaller Calyptrotheca-like shrubs (Carlquist 1998a; Applequist and Wallace 2000). Also, with regard to the lengthon-age curves for vessel elements, the link between Carlquistian paedomorphosis and secondary woodiness is not straightforward: Mabberley (1974) emphasizes that the shape of the curves depends on the position in the stem and does not fit with Carlquist's ideas on paedomorphosis, while it has been known for a long time that flat length-on-age curves for vessel elements are characteristic of primarily woody species with storied cambia (Bailey 1923). In conclusion, protracted juvenilism in wood features is present in secondarily woody species, but these wood features seem to be more closely associated with primarily or secondarily woody taxa that have specific plant habits.

If protracted juvenilism is indeed strongly linked to life forms showing limited growth, then these characters should have a function. For instance, Carlquist (2012) hypothesized that upright ray cells in wood are more efficient than square or procumbent ones in vertical flow of sugar transport, which would make sense because radial transport in woody taxa with limited wood accumulation is of less significance. That may explain why upright ray cells are gradually replaced by procumbent ray cells in mature wood of tall secondarily woody trees, such as Nesobedyotis, that can grow up to $7 \mathrm{~m}$ in height (Lens et al. 2009). Likewise, wide-gaping intervessel pits are often present in the wood of stem succulents, which may or may not be secondarily woody. Apparently, the vessel walls in these succulents do not need to be reinforced mechanically by 
smaller pits, likely because the turgor pressure in the waterfilled cells provide enough mechanical strength (Dulin and Kirchoff 2010). A possible function for the flat or continuously decreasing length-on-age curves of vessel elements in woody plants has not been forthcoming. Vessel elements are known to be shorter in species from dry environments (Carlquist 1966; Baas et al. 1983) or in small shrubs (Baas et al. 1984), and there might be a greater chance for air bubbles to be trapped more frequently near the vessel element tails when vessel elements are shorter (Carlquist 2012). However, there is general consensus that the length of entire vessels greatly overwhelms the importance of vessel element length in the water transport mechanism of plants (Sperry et al. 2007; Lens et al. 2011).

\section{Why Does Insular Woodiness Occur on the Canary Islands and Beyond?}

A sound explanation for why insular woodiness has evolved so many times in parallel during the evolution of flowering plants on islands is lacking. Various island hypotheses have been put forward, such as (1) the competition hypothesis (plants gain competitive advantage by growing taller into shrubs and trees; Darwin 1859; Tilman 1988; Givnish 1995), (2) the longevity hypothesis (woody plants live longer and are able to produce more seeds; Wallace 1878), (3) the moderateinsular-climate hypothesis (release from seasonality allows herbs to grow throughout the year and become woody; Carlquist 1974, 2012), and (4) the herbivore hypothesis (absence of large native herbivores on islands allows herbaceous plants to grow longer and become woody; Carlquist 1974). The first hypothesis was extended by Givnish (1998; taxon-cycling hypothesis) and the second by Böhle et al. (1996; promotion-ofoutcrossing hypothesis), but convincing experimental data for all these hypotheses are scarce to absent. For instance, in an attempt to investigate the adaptive significance of herbaceous plant height in the understory of forests, a $7 \%$ increase in leaf cover of herbaceous plants led roughly to a doubled maximum leaf height (proxy for plant height). In other words, herbaceous species growing in dense herb communities develop taller stems than do herbaceous species occurring in low-density herb habitats, which is in line with the competition hypothesis (Givnish 1982). However, to our knowledge, it has not been proved that island species would grow in higher-density communities than continental species. The outcrossing hypothesis was supported by field observations on St. Helena investigating the tall Nesobedyotis arborea trees up to $7 \mathrm{~m}$. The trees showed limited gene flow, which would be likely more severe in smallerstature plants (Percy and Cronk 1997).

We agree with Carlquist that a moderate climate, in particular the absence of frost temperatures, in most of the oceanic islands is definitely an important condition for herbaceous plants to develop insular woodiness. Interestingly, Sinnott and Bailey (1915) argued that the onset of cold winters in the temperate zones, due to refrigeration of the climate since the beginning of the Tertiary, caused the evolution from primary woodiness toward herbaceousness. This old idea can be confirmed by our ongoing broad-scale secondary review project, which shows that secondarily woody species generally do not occur in cold temperate or boreal to arctic regions where frost regularly occurs. However, some secondarily woody species do survive frost, es- pecially in tropical alpine environments, such as the pachycaul rosette trees of Espeletia (Rauscher 2002), Dendrosenecio (Nordenstam et al. 2009), and lobelioids (Givnish et al. 2009); the small, shrubby Hawaiian species of Silene (Eggens et al. 2007); and some shrubby Canarian groups (table 1). Our broad-scale review also indicates that a single environmental variable such as temperature cannot be the only explanation driving increased woodiness: secondarily woody species hardly occur in lowland tropical rain forests, but they do occur in diverse warm habitats ranging from very wet tropical forests of, among others, the Hawaiian Islands (Asinidendron; Weller et al. 1995) or Southeast Asia and the Pacific (Cyrtandra; Cronk et al. 2005) to markedly dry deserts, such as coastal regions of Peru and Chile (Nolana; Dillon et al. 2007) or the North African deserts (Henophyton; Warwick et al. 2010). Most likely, a complex mix of abiotic and biotic factors can induce secondary woodiness in many groups, and these variables may change, depending on the group under study.

We believe that-at least in some herbaceous groupsdrought may trigger wood formation, which has never been hypothesized before in relation to secondary woodiness. This idea comes from our ongoing review, which demonstrates that a majority of the angiosperm genera that include secondarily woody species are restricted to dry continental regions with at least a few months of drought per year (coastal Mediterranean regions, steppes in Central Asia, and even [semi-]deserts across the world; F. Lens, unpublished data). A possible link between insular woodiness and dry habitats can also be confirmed for the Canary Island flora, where $58 \%$ of the insular woody species grow in the dry coastal regions up to $700 \mathrm{~m}$ asl (fig. $1 B$ ) and another $6 \%$ grow in the high-altitude desert above $2000 \mathrm{~m}$ asl (fig. 1G), while only $11 \%$ are found in the humid laurel forests (fig. $1 A$ ). Moreover, plotting habitat type data on molecular phylogenies supports the hypothesis that the dry habitats are ancestral within Canary Island clades exhibiting insular woodiness, as intensively studied in, for instance, Descurainia (Goodson et al. 2006), Echium (GarcíaMaroto et al. 2009), and Micromeria (Meimberg et al. 2006). Although plants can rely on different mechanisms to cope with drought stress (deep root systems, $\mathrm{C}_{4}$ or CAM metabolism, stem succulence, leaf adaptations), additional evidence for this new hypothesis could be found in the ability of stems to avoid air bubble formation (i.e., embolism resistance) in vessels. A direct causal link between survival of plants and embolism resistance during extreme drought has been highlighted, suggesting that embolism resistance is an important adaptive trait (Maherali et al. 2004; Brodribb and Cochard 2009; Brodribb et al. 2010; Choat et al. 2012). At this moment, no experiments have been carried out showing that embolism resistance in stems of insular woody species would be stronger than that in the stems of closely related herbaceous species. However, there are preliminary results in Arabidopsis that may point to this correlation: Tixier et al. (2013) found that short-day Arabidopsis thaliana plants with more wood development are significantly more embolism resistant than long-day plants with less wood development. Moreover, embolism resistance in stems of the woody mutant is $\sim 1 \mathrm{MPa}$ more negative than the values obtained for the wild-type stems (Lens et al. 2013). Future experiments will indicate whether this assumption can be generalized using additional species growing in the wild. 


\section{Herbaceousness Prevails in Canary Island Angiosperms}

Despite massive convergent evolutionary trends toward insular woodiness on the Canary Islands, it is intriguing to see that the majority of native angiosperms have never evolved to insular woodiness $(66 \%$ of the angiosperm species, $59 \%$ of the native traditional dicots, and $34 \%$ of the endemics are herbaceous; table 2). As most herbaceous traditional dicot species still produce a small amount of wood at the base of their stems (Carlquist 2009; Dulin and Kirchoff 2010; Schweingruber et al. 2011; Lens et al. 2012a, 2012b), it is unlikely that the ability to turn on the molecular wood pathway has been lost in these species. This is suggested in the herbaceous model plant $A$. thaliana, which develops into a woody shrub by knocking out only two flowering-time genes (Melzer et al. 2008). Moreover, there is growing evidence that at least some key genes associated with the shoot apical meristem are also expressed in the cambial zone during secondary growth (Schrader et al. 2004; Aichinger et al. 2012), explaining why there is a strong evolutionary pressure for these wood-inducing genes to be maintained in herbaceous plants (Spicer and Groover 2010). Anyway, many herbaceous lineages on the Canary Islands were not triggered to develop into shrubs, and this does not seem to be disadvantageous, considering the vast number of herbs. The lack of development into shrubs might be related to (1) much shorter generation times, leading to higher rates of molecular evolution (Smith and Donoghue 2008), (2) the possible occurrence in specific microhabitats that do not require much allocation of energy and resources in wood formation within stems, (3) the ability of herbaceous species to deal with unfavorable periods as seeds (avoidance strategy), or (4) gene mutations blocking (part of) the molecular wood pathway. In the literature, several potential advantages of shrubbiness over herbaceousness are mentioned (Stutz 1989), such as a reuse of old tissue (more energy efficient), taller habit (harvesting more sunlight), or photosynthesis during the entire year (through evergreen leaves or chlorophyll contained in the bark of overwintering stems). Among the endemic species within the traditional dicots (table 2), the 202 insular woody species slightly outnumber the 174 herbaceous species, assuming that both life forms represent equally advantageous strategies to cope with the environmental conditions on the Canaries.

Surprisingly, the Canary monocots include only 25 endemics, of which one (Dracaena tamaranae) forms a vascular cambium producing amphivasal vascular bundles embedded in parenchyma to the inside and parenchyma to the outside, a peculiar monocot anatomy characteristic of the entire genus (Cheadle 1937; Tomlinson and Zimmermann 1969). This form of secondary growth in Dracaena is not an island phenomenon, however, since the distribution of the genus extends to the warmer regions of the Old World (Bos 1998). Also, species of the genus Asparagus are described as shrubs, but on the basis of original anatomical sections, there is no sign of vascular cambium formation (fig. $2 F$; cf. the native palm species Phoenix canariensis).

\section{Suggestions for Future Research}

Besides screening for more secondarily woody species around the world, future research on secondary woodiness should be focusing on the questions (1) Why do herbaceous species develop into shrubs? and (2) What is the molecular pathway that triggers wood development in secondarily woody species? We propose an integration of ecology, evolution, and developmental studies (eco-evo-devo), which is a modern approach in systematics to bridge understanding between genotype and phenotype, to contribute to solving these major questions.

1. Integrating georeferenced environmental data and evolutionary biology is an efficient way to reveal new insights into the ecological causes of evolutionary patterns (Kozak et al. 2008; Evans et al. 2009; Yesson et al. 2009; Boucher et al. 2012). On the basis of this niche-modeling approach, we hope to find environmental variables that are tightly linked to either the insular woody or the herbaceous life form on the Canary Islands. If it turns out that drought resistance parameters play an important role in at least some of the secondarily woody groups, experimental hydraulic experiments will be performed in herbaceous and woody stems to validate whether secondarily woody stems are more embolism resistant than stems of herbaceous relatives (Lens et al. 2013).

2. The woody Arabidopsis lab mutant shows that a "simple" genetic mechanism can turn an herb into a secondarily woody shrub, demonstrating that at least some herbaceous plants retain the genetic capability to develop into woody shrubs (Oh et al. 2003; Groover 2005; Spicer and Groover 2010), but we need to identify how the "flowering-time" signal is transferred to the "woody-growth" regulator in this species. A next step would be to compare the results in Arabidopsis to those in insular woody species in different branches of the angiosperm tree of life, using comparative transcriptomics of nonmodel species (Strickler et al. 2012). This strategy will allow us to find whether homoplastic evolution toward secondary woodiness in flowering plants develops via a similar molecular mechanism (parallel evolution) or whether dissimilar molecular pathways are responsible for these independent shifts (convergent evolution; Scotland 2011). Before this is clarified, it is better to describe an independent evolution of a given phenotype as convergence (Scotland 2011).

One of the most remarkable habit shifts on the Canary Islands is the evolution of some insular woody groups toward secondary herbaceousness. This has happened at least three times in Echium (García-Maroto et al. 2009) and once in Sonchus (Kim et al. 2007). These two genera provide excellent case studies to investigate the habit shifts in more detail.

\section{Acknowledgments}

We would like to thank Dr. Quentin Cronk and Dr. Mark Olson for their useful review comments, the Naturalis Biodiversity Center for financial support of our insular-woodiness project, and Dr. B. Gravendeel and Dr. V. Garzón-Machado for their help during the collecting trip in Tenerife. We dedicate this review to Dr. Sherwin Carlquist, who made many invaluable contributions to the research of insular woodiness and remains a continuous source of inspiration. 


\section{Literature Cited}

Aichinger E, N Kornet, T Friedrich, T Laux 2012 Plant stem niches. Annu Rev Plant Biol 63:615-636.

Akhani H, G Edwards, EH Roalson 2007 Diversification of the Old World Salsoneae s.l. (Chenopodiaceae): molecular phylogenetic analysis of nuclear and chloroplast data sets and a revised classification. Int J Plant Sci 168:931-956.

Albach DC, HM Meudt, B Oxelman 2005 Piecing together the "new" Plantaginaceae. Am J Bot 92:297-315.

Allan GJ, J Francisco-Ortega, A Santos-Guerra, E Boerner, EA Zimmer 2004 Molecular phylogenetic evidence for the geographic origin and classification of Canary Island Lotus (Fabaceae: Loteae). Mol Phylogenet Evol 32:123-128.

Allan GJ, JM Porter 2000 Tribal delimitation and phylogenetic relationships of Loteae and Coronilleae (Faboideae: Fabaceae) with special reference to Lotus: evidence from nuclear ribosomal ITS sequences. Am J Bot 87:1871-1881.

Anderberg AA 2009 Inuleae. Pages 667-680 in VA Funk, A Susanna, TF Stuessy, RJ Bayer, eds. Systematics, evolution, and biogeography of Compositae. International Association for Plant Taxonomy, Vienna.

Anderberg AA, BG Baldwin, RG Bayer, J Breitwieser, C Jeffrey, MO Dillon, P Eldenäs, et al 2007 Compositae. Pages 61-588 in JW Kadereit, C Jeffrey, eds. The families and genera of vascular plants. Vol 8. Asterales. Springer, Berlin.

Anjen L, AE Grabovskaya-Borodina, SL Mosyakin 2003 Rumex Pages 333-341 in ZY Wu, PH Raven, DY Hong, eds. Flora of China. Vol 5. Science Press, Beijing; Missouri Botanical Garden Press, St. Louis.

APG (Angiosperm Phylogeny Group) III 2009 An update of the Angiosperm Phylogeny Group classification for the orders and families of flowering plants: APG III. Bot J Linn Soc 161:105-121.

Appel O, IA Al-Shehbaz 2003 Cruciferae. Pages 75-174 in K Kubitzki, C Bayer, eds. The families and genera of vascular plants. Vol 5. Malvales, Capparales and non-betalain Caryophyllales. Springer, Berlin.

Applequist WL, RS Wallace 2000 Phylogeny of the Madagascan endemic family Didiereaceae. Plant Syst Evol 221:157-166.

Arechavaleta M, S Rodriguez, N Zurita, A García 2010 Lista de especies silvestres de Canarias: hongos, plantas y animales terrestres. 2009. Gobierno de Canarias, Tenerife. 579 pp.

Baas P, CL Lee, XY Zhang, KM Cui, YF Deng 1984 Some effects of dwarf growth on wood structure. IAWA Bull, NS, 5:45-63.

Baas P, E Werker, A Fahn 1983 Some ecological trends in vessel characters. IAWA Bull, NS, 4:141-159.

Bailey IW 1923 The cambium and its derivative tissues. IV. The in crease in girth of the cambium. Am J Bot 10:499-508.

Baldwin BG, DW Kyhos, J Dvorak, GD Carr 1991 Chloroplast DNA evidence for a North American origin of the Hawaiian silversword alliance (Asteraceae). Proc Natl Acad Sci USA 88:1840-1843.

Baldwin BG, MJ Sanderson 1998 Age and rate of diversification of the Hawaiian silversword alliance (Compositae). Proc Natl Acad Sci USA 95:9402-9406.

Ballard HE Jr, KJ Sytsma 2000 Evolution and biogeography of the woody Hawaiian violets (Viola, Violaceae): Arctic origins, herbaceous ancestry and bird dispersal. Evolution 54:1521-1532.

Barber JC, J Francisco-Ortega, A Santos-Guerra, KG Turner, RK Jansen 2002 Origin of Macaronesian Sideritis L. (Lamioideae: Lamiaceae) inferred from nuclear and chloroplast sequence datasets. Mol Phylogenet Evol 23:293-306.

Bayer C, K Kubitzki 2003 Malvaceae. Pages 225-311 in K Kubitzki, C Bayer, eds. The families and genera of vascular plants. Vol 5 . Malvales, Capparales and non-betalain Caryophyllales. Springer, Berlin.
Beilstein MA, IA Al-Shehbaz, S Mathews, EA Kellogg 2008 Brassicaceae phylogeny inferred from phytochrome A and $n d h F$ sequence data: tribes and trichomes revisited. Am J Bot 95:1307-1327.

Bendiksby M, L Thorbek, A-C Scheen, C Lindqvist, O Ryding 2011 An updated phylogeny and classification of Lamiaceae subfamily Lamioideae. Taxon 60:471-484.

Bittrich V 1993 Caryophyllaceae. Pages 206-236 in K Kubitzki, JG Rohwer, V Bittrich, eds. The families and genera of vascular plants. Vol 2. Magnoliid, hamamelid and caryophyllid families. Springer, Berlin.

Böhle UR, HH Hilger, WF Martin 1996 Island colonization and evolution of the insular woody habit in Echium L. (Boraginaceae). Proc Natl Acad Sci USA 93:11740-11745.

Borgen L 1987 Lobularia (Cruciferae): a biosystematic study with special reference to the Macaronesian region. Opera Bot 91:1-96.

Bos JJ 1998 Dracaenaceae. Pages 238-241 in K Kubitzki, ed. The families and genera of vascular plants. Vol 3. Monocotyledons: Lilianae (except Orchidaceae). Springer, Berlin.

Boucher FC, W Thuiller, C Roquet, R Douzet, S Aubert N Alvarez, S Lavergne 2012 Reconstructing the origins of high-alpine niches and cushion life form in the genus Androsace s.l. (Primulaceae). Evolution 66:1255-1268.

Bramwell D 1970 A revision of the genus Parolinia Webb (Cruciferae) in the Canary Islands. Bot Not 123:394-400.

1972 Endemism in the flora of the Canary Islands. Pages 141159 in DH Valentin, ed. Taxonomy, phytogeography and evolution. Academic Press, London.

Bramwell D, ZI Bramwell 1974 Wild flowers of the Canary Islands. Stanley Thornes, London.

Bramwell D, J Caujapé-Castells, eds 2011 The biology of island floras. Cambridge University Press, Cambridge.

Brandbyge J 1993 Polygonaceae. Pages 531-544 in K Kubitzki, JG Rohwer, V Bittrich, eds. The families and genera of vascular plants. Vol 2. Magnoliid, hamamelid and caryophyllid families. Springer, Berlin.

Bräuchler C, H Meimberg, G Heubl 2010 Molecular phylogeny in Menthinae (Lamiaceae, Nepetoideae, Mentheae): taxonomy, biogeography and conflicts. Mol Phylogenet Evol 55:501-523.

Bremer B, T Eriksson 2009 Time tree of Rubiaceae: phylogeny and dating the family, subfamilies, and tribes. Int J Plant Sci 170:766793.

Brodribb TJ, D Bowman, S Nichols, S Delzon, R Burlett 2010 Xylem function and growth rate interact to determine recovery rates after exposure to extreme water deficit. New Phytol 188:533-542.

Brodribb TJ, H Cochard 2009 Hydraulic failure defines the recovery and point of death in water-stressed conifers. Plant Physiol 149: 575-584.

Burke JM, A Sanchez, K Kron, M Luckow 2010 Placing the woody tropical genera of Polygonaceae: a hypothesis of character evolution and phylogeny. Am J Bot 97:1377-1390.

Calviño CI, SG Martínez, SR Downie 2010 Unraveling the taxonomic complexity of Eryngium L. (Apiaceae, Saniculoideae): phylogenetic analysis of 11 non-coding cpDNA loci corroborates rapid radiations. Plant Divers Evol 128:137-149.

Cannon MJ 1994 Umbelliferae (Apiaceae). Pages 238-248 in JR Press and MJ Short, eds. Flora of Madeira. Natural History Museum, London.

Carine MA 2005 Spatio-temporal relationships of the Macaronesian endemic flora: a relictual series of window or opportunity? Taxon 54:895-903.

Carine MA, SJ Russell, A Santos-Guerra, J Francisco-Ortega 2004 Relationships of the Macaronesian and Mediterranean floras: molecular evidence for multiple colonizations into Macaronesia and 
back-colonization of the continent in Convolvulus (Convolvulaceae). Am J Bot 91:1070-1085.

Carlquist S 1962 A theory of paedomorphosis in dicotyledonous woods. Phytomorphology 12:30-45.

- 1966 Wood anatomy of Compositae: a summary with comments on factors controlling wood evolution. Aliso 6:25-44.

— $1969 a$ Wood anatomy of Goodeniaceae and the problem of insular woodiness. Ann Mo Bot Gard 56:358-390.

$1969 b$ Wood anatomy of Lobelioideae (Campanulaceae). Biotropica 1:47-72.

— 1970a Wood anatomy of Echium (Boraginaceae). Aliso 7: 183-199.

$1970 b$ Wood anatomy of Hawaiian, Macaronesian, and other species of Euphorbia. Bot J Linn Soc 63(suppl 1):181-193.

$1970 c$ Wood anatomy of insular species of Plantago and the problem of raylessness. Bull Torrey Bot Club 97:353-361.

1971 Wood anatomy of Macaronesian and other Brassicaceae. Aliso 7:365-384.

1974 Insular woodiness. Pages 350-428 in Island biology. Columbia University Press, New York.

1982 Wood anatomy of Dipsacaceae. Taxon 31:443-450.

1984 Wood anatomy of some Gentianaceae: systematic and ecological conclusions. Aliso 10:573-582.

1985 Wood anatomy of Begoniaceae, with comments on raylessness, paedomorphosis, relationships, vessel diameter, and ecology. Bull Torrey Bot Club 112:29-69.

1989 Wood and bark anatomy of Empetraceae; comments on paedomorphosis in woods of certain small shrubs. Aliso 12:497515 .

- $1992 a$ Wood anatomy of Lamiaceae: a survey, with comments on vascular and vasicentric tracheids. Aliso 13:309-338.

— $1992 b$ Wood anatomy of sympetalous dicotyledon families: a summary, with comments on systematic relationships and evolution of the woody habit. Ann Mo Bot Gard 79:303-332.

1995 Wood anatomy of Caryophyllaceae: ecological, habital, systematic, and phylogenetic implications. Aliso 14:1-17.

- 1998a Wood anatomy of Portulacaceae and Hectorellaceae: ecological, habital, and systematic implications. Aliso 16:137-153.

— $1998 b$ Wood anatomy of Resedaceae. Aliso 16:127-135.

- 2003a Wood anatomy of Polygonaceae: analysis of a family with exceptional wood diversity. Bot J Linn Soc 141:25-51.

2009 Xylem heterochrony: an unappreciated key to angiosperm origins and diversifications. Bot J Linn Soc 160:26-65.

2012 How wood evolves: a new synthesis. Botany 90:901940.

Carlquist S, VM Eckhart 1982 Wood anatomy of Darwiniothamnus, Lecodarpus, and Macraea (Asteraceae). Aliso 10:291-300.

Carlquist S, MA Hanson 1991 Wood and stem anatomy of Convolvulaceae: a survey. Aliso 13:51-94.

Carlson SE, V Mayer, MJ Donoghue 2009 Phylogenetic relationships, taxonomy, and morphological evolution in Dipsacaceae (Dipsacales) inferred by DNA sequence data. Taxon 58:1075-1091.

Caujapé-Castells J 2011 Jesters, red queens, boomerangs and surfers: a molecular outlook on the diversity of the Canarian endemic flora. Pages 284-324 in D Bramwell, J Caujapé-Castells, eds. The biology of island floras. Cambridge University Press, Cambridge.

Cheadle VI 1937 Secondary growth by means of a thickening ring in certain monocotyledons. Bot Gaz 98:535-555.

Choat B, S Jansen, TJ Brodribb, H Cochard, S Delzon, R Bhaskar, S Bucci, et al 2012 Global convergence in the vulnerability of forests to drought. Nature 491:752-756.

Coello J, JM Cantagrel, F Hernán, JM Fúster, E Ibarrola, E Ancochea, C Casquet, C Jamond, JR Díaz de Téran, A Cendrero 1992 Evolution of the eastern volcanic ridge of the Canary Islands based on new K-Ar data. J Volcanol Geotherm Res 53:251-274.

Crawford DJ, M Tadesse, ME Mort, RT Kimball, CP Randle
2009 Coreopsideae. Page 713-730 in VA Funk, A Susanna, TF Stuessy, RJ Bayer, eds. Systematics, evolution, and biogeography of Compositae. International Association for Plant Taxonomy, Vienna.

Cronk QCB 1987 The history of endemic flora of St Helena: a relictual series. New Phytol 105:509-520.

1992 Relict floras of the Atlantic islands: patterns assessed. Biol J Linn Soc 46:91-103.

Cronk QCB, M Kiehn, WL Wagner, JF Smith 2005 Evolution of Cyrtandra (Gesneriaceae) in the Pacific Ocean: the origin of a supertramp clade. Am J Bot 92:1017-1024.

Cumbie BG 1983 Developmental changes in the wood of Bocconia vulcanica Donn. Smith. IAW Bull, NS, 4:131-140.

Darwin C 1859 On the origin of species by means of natural selection. J Murray, London.

del Arco MJ, R González-González, V Garzó-Machado, B Pizarro 2010 Actual and potential natural vegetation on the Canary Islands and its conservation status. Biodivers Conserv 19:30893140.

Dillon MO, $\mathrm{T}$ Tu, A Soejima, $\mathrm{T}$ Yi, Z Nie, A Tye, J Wen 2007 Phylogeny of Nolana (Nolaneae, Solanoideae, Solanaceae) as inferred from granule-bound starch synthase I (GBSSI) sequences. Taxon 56:1000-1011.

Dulin MW, BK Kirchoff 2010 Paedomorphosis, secondary woodiness, and insular woodiness in plants. Bot Rev 76:405-490.

Dunbar-Co S, AM Wieczorek, CW Morden 2008 Molecular phylogeny and adaptive radiation of the endemic Hawaiian Plantago species (Plantaginaceae). Am J Bot 95:1177-1188.

Eggens F, M Popp, M Nepokroeff, WL Wagner, B Oxelman 2007 The origin and number of introductions of the Hawaiian endemic Silene species (Caryophyllaceae) Am J Bot 94:210-218.

Ehrendorfer F, E Schönbeck-Temesy 2005 Rubia. Pages 48-72 in KH Rechinger, ed. Flora Iranica. Fasc 176. Rubiaceae. Akademische, Graz.

Emerson BC 2002 Evolution on oceanic islands: molecular phylogenetic approaches to understanding patterns and process. Mol Ecol 11:951-966.

Epling C 1938 The Californian salvias: a review of Salvia, section Audibertia. Ann Mo Bot Gard 25:1-94.

Escobar García P, P Schönswetter, JF Aguilar, GN Feliner, GM Schneeweiss 2008 Five molecular markers reveal extensive morphological homoplasy and reticulate evolution in the Malva alliance (Malvaceae). Mol Phylogenet Evol 50:226-239.

Evans ME, SA Smith, RS Flynn, MJ Donoghue 2009 Climate, niche evolution and diversification of the "bird-cage" evening primroses (Oenothera, sections Anogra and Kleinia). Am Nat 173:225-240.

Feodorova TA, EV Voznesenskaya, GE Edwards, EH Roalson 2010 Biogeographic patterns of diversification and the origins of $\mathrm{C}_{4}$ in Cleome (Cleomaceae). Syst Bot 35:811-826.

Fernández-Palacios JM, L de Nascimento, R Otto, JD Delgado, E García-del-Rey, JR Arévalo, RJ Whittaker 2009 A reconstruction of Palaeo-Macaronesia, with particular reference to the long-term biogeography of the Atlantic island laurel forests. J Biogeogr 38: 226-246.

Fischer E 2004 Scrophulariaceae. Pages 333-432 in JW Kadereit, ed. The families and genera of vascular plants. Vol 7. Lamiales (except Acanthaceae, including Avicenniaceae). Springer, Berlin.

Fiz O, P Vargas, M Alarcón, C Aedo, LJ García, JJ Aldasoro 2008 Phylogeny and historical biogeography of Geraniaceae in relation to climate changes and pollination ecology. Syst Bot 33:326342.

Francisco-Ortega J, JC Barber, A Santos-Guerra, R Febles-Hernández, RK Jansen 2001a Origin and evolution of the endemic genera of Gonosperminae (Asteraceae: Anthemideae) from the Canary Islands: evidence from nucleotide sequences of the internal transcribe spacers of the nuclear ribosomal DNA. Am J Bot 88:161-169.

Francisco-Ortega J, Fuertes-Aguilar, C Gómez-Campo, A Santos- 
Guerra, RK Jansen 1999 Internal transcribed spacer sequence phylogeny of Crambe L. (Brassicaceae): molecular data reveal two Old World disjunctions. Mol Phylogenet Evol 11:361-380.

Francisco-Ortega J, Fuertes-Aguilar, SC Kim, A Santos-Guerra, DJ Crawford, RK Jansen 2002 Phylogeny of the Macaronesian endemic Crambe section Dendrocrambe (Brassicaceae) based on internal transcribed spacer sequences of nuclear ribosomal DNA. Am J Bot 89:1984-1990.

Francisco-Ortega J, S-J Park, A Santos-Guerra, A Benabid, RK Jansen $2001 b$ Origin and evolution of the endemic Macaronesian Inuleae (Asteraceae): evidence from the internal transcribed spacers of nuclear ribosomal DNA. Biol J Linn Soc 72:77-97.

Francisco-Ortega J, A Santos-Guerra, A Hines, RK Jansen 1997 Molecular evidence for a Mediterranean origin of the Macaronesian endemic genus Argyranthemum (Asteraceae). Am J Bot 84:1595-1613.

Franzke A, D German, IA Al-Shebahz, K Mummenhoff 2009 Arabidopsis family ties: molecular phylogeny and age estimates in Brassicaceae. Taxon 58:425-437.

Fuertes-Aguilar J, MF Ray, J Francisco-Ortega, A Santos-Guerra, RK Jansen 2002 Molecular evidence from chloroplast and nuclear markers for multiple colonizations of Lavatera (Malvaceae) in the Canary Islands. Syst Bot 27:74-83.

García-Maroto F, A Mañas-Fernández, JA Garrido-Cárdenas, D López Alonso, JL Guil-Guerrero, B Guzmán, P Vargas $2009 \Delta^{6}$-desaturase sequence evidence for explosive Pliocene radiations within the adaptive radiation of Macaronesian Echium (Boraginaceae). Mol Phylogenet Evol 52:563-574.

García-Talavera F 1997 Las Canarias orientales y la vecina costa Africana en el Holoceno. Eres 7:5-63.

Geldmacher J, K Hoernle, P van den Bogaard, G Zankl, D GarbeSchönberg 2001 Earlier history of the $\geq 70$-Ma-old Canary hotspot based on temporal and geochemical evolution of the Selvagen Archipelago and neighboring seamounts in the eastern North Atlantic. J Volcanol Geotherm Res 111:55-87.

Ghebrehiwet M 2001 Taxonomy, phylogeny and biogeography of Kickxia and Nanorrhinum (Scrophulariaceae). Nord J Bot 20:655690.

Givnish TJ 1982 On the adaptive significance of leaf height in forest herbs. Am Nat 120:353-381.

1995 Plant stems: biomechanical adaptation for energy capture and influence on species distributions. Pages 3-49 in BL Gartner, ed. Plant stems: physiology and functional morphology. Chapman \& Hall, New York.

- 1998 Adaptive plant evolution on islands: classical patterns, molecular data, new insights. Pages 281-304 in PR Grant, ed. Evolution on islands. Oxford University Press, Oxford.

Givnish TJ, KC Millam, AR Mast, TB Paterson, TT Theim, AL Hipp, LM Henss, JF Smith, KR Wood, KJ Sytsma 2009 Origin, adaptive radiation and diversification of the Hawaiian lobeliads (Asterales: Campanulaceae). Proc R Soc B 276:407-416.

Goertzen LR, J Francisco-Ortega, A Santos-Guerra, JP Mower, CR Linder, RK Jansen 2002 Molecular systematics of the Asteriscus alliance (Asteraceae: Inuleae) II: combined nuclear and chloroplast data. Syst Bot 27:815-823.

Goodson BA, A Santos-Guerra, RK Jansen 2006 Molecular systematics of Descurainia (Brassicaceae) in the Canary Islands: biogeographic and taxonomic implications. Taxon 55:671-682.

Greenberg AK, MJ Donoghue 2011 Molecular systematics and character evolution in Caryophyllaceae. Taxon 60:1637-1652.

Groover AT 2005 What genes make a tree a tree? Trends Plant Sci 10:210-214.

Halvorsen T, L Borgen 1986 The perennial Macaronesian species of Bubonium (Compositae-Inuleae). Sommerfeltia 3:1-103.

Harbaugh DT, M Nepokroeff M, RK Rabeler, J McNeill, EA Zimmer,
WL Wagner 2010 A new lineage-based tribal classification of the family Caryophyllaceae. Int J Plant Sci 171:185-198.

Hedge C 1974 A revision of Salvia in Africa including Madagascar and the Canary Islands. Notes R Bot Gard Edinb 33:1-121.

Heklau H, P Gasson, F Schweingruber, P Baas 2012 Wood anatomy of Chenopodiaceae (Amaranthaceae s.l.). IAWA J 33:205-232.

Hopkins CO, WH Blackwell Jr 1977 Synopsis of Suaeda (Chenopodiaceae) in North America. Sida 7:147-173.

Horn JW, BW van Ee, JJ Morawetz, R Riina, VW Steinmann, PE Berry, KJ Wurdack 2012 Phylogenetics and the evolution of major structural changes in the giant genus Euphorbia L. (Euphorbiaceae). Mol Phylogenet Evol 63:305-326.

Hufford L, MM McMahon, AM Sherwood, G Reeves, MW Chase 2003 The major clades of Loasaceae: phylogenetic analysis using the plastid matK and trnL-trnF regions. Am J Bot 90:12151228.

Kadereit G, H Freitag 2011 Molecular phylogeny of Camphorosmeae (Camphorosmoideae, Chenopodiaceae): implications for biogeography, evolution of $\mathrm{C}_{4}$-photosynthesis and taxonomy. Taxon 60:5178 .

Kadereit G, L Mucina, H Freitag 2006 Phylogeny of Salicornioideae (Chenopodiaceae): diversification, biogeography, and evolutionary trends in leaf and flower morphology. Taxon 55:617-642.

Khosravi AR, S Mohsenzadeh, K Mummenhoff 2009 Phylogenetic relationships of Old World Brassicaceae from Iran based on nuclear ribosomal DNA sequences. Biochem Syst Ecol 37:106-115.

Kilian N 1997 Revision of Launaea Cass. (Compositae, Lactuceae, Sonchinae). Englera 17:1-478.

Kilian N, B Gemeinholzer, HW Lack 2009 Cichorieae. Pages 343383 in VA Funk, A Susanna, TF Stuessy, RJ Bayer, eds. Systematics, evolution, and biogeography of Compositae. International Association for Plant Taxonomy, Vienna.

Kim S-C, L Chunghee, JA Mejias 2007 Phylogenetic analysis of chloroplast DNA matK gene and ITS of nrDNA sequences reveals polyphyly of the genus Sonchus and new relationships among the subtribe Sonchinae (Asteraceae: Cichorieae). Mol Phylogenet Evol 44: 578-597.

Kim S-C, MR McGowen, P Lubinsky, JC Barber, ME Mort, A SantosGuerra 2008 Timing and tempo of early and successive adaptive radiations in Macaronesia. PloS ONE 3:e2139.

Koek-Noorman J 1976 Juvenile wood characters in the wood of certain Rubiaceae with special reference to Rubia fruticosa Ait. IAWA Bull, NS, 3:38-42.

Kowal E, DF Cutler 1974 The wood anatomy of Schouwia purpurea subsp. arabica and Fabrisinapis fruticosus (Cruciferae). Kew Bull 30:503-507.

Kozak KH, CH Graham, JJ Wiens 2008 Integrating GIS-based environmental data into evolutionary biology. Trends Ecol Evol 23: 141-148.

Kubitzki K 2003 Resedaceae. Pages 334-338 in K Kubitzki, C Bayer, eds. The families and genera of vascular plants. Vol 5. Malvales, Capparales and non-betalain Caryophyllales. Springer, Berlin.

Kühn U 1993 Chenopodiaceae. Pages 253-281 in K Kubitzki, JG Rohwer, V Bittrich, eds. The families and genera of vascular plants. Vol 2. Magnoliid, hamamelid and caryophyllid families. Springer, Berlin.

Lems K 1960 Botanical notes on the Canary Islands. II. The evolution of plant forms in the islands: Aeonium. Ecology 41:1-17.

Lens F, S Eeckhout, R Zwartjes, E Smets, SB Janssens 2012a The multiple fuzzy origins of woodiness within Balsaminaceae using an integrated approach: where do we draw the line? Ann Bot 109:783799.

Lens F, P Gasson, E Smets, S Jansen 2003 Comparative wood anatomy of epacrids (Styphelioideae, Ericaceae s.l.). Ann Bot 91:835857.

Lens F, I Groeninckx, E Smets, D Dessein 2009 Woodiness within the 
Spermacoceae-Knoxieae alliance (Rubiaceae): retention of the basal woody condition in Rubiaceae or recent innovation? Ann Bot 103: 1049-1064.

Lens F, J Schönenberger, P Baas, S Jansen, E Smets 2007 The role of wood anatomy in phylogeny reconstruction of Ericales. Cladistics 23:229-254.

Lens F, E Smets, S Melzer $2012 b$ Stem anatomy supports Arabidopsis thaliana as a model for insular woodiness. New Phytol 193:12-17.

Lens F, JS Sperry, MA Christman, B Choat, D Rabaey, S Jansen 2011 Testing hypotheses that link wood anatomy to cavitation resistance and hydraulic conductivity in the genus Acer. New Phytol 190:709-723

Lens F, A Tixier, H Cochard, JS Sperry, S Jansen, S Herbette 2013 Embolism resistance as a key mechanism to understand adaptive plant strategies. Curr Opin Plant Biol 16:287-292.

Losos JB, RE Ricklefs 2009 Adaptation and diversification on islands. Nature 457:830-836.

Mabberley DJ 1974 Pachycauly, vessel elements, islands and the evolution of arborescence in "herbaceous" families. New Phytol 73: 977-984.

Maherali H, WT Pockman, JB Jackson 2004 Adaptive variation in the vulnerability of woody plants to xylem cavitation. Ecology 85 : 2184-2199.

Mansion G, L Struwe 2004 Generic delimitation and phylogenetic relationships within the subtribe Chironiinae (Chironieae: Gentianaceae), with special reference to Centaurium: evidence from nrDNA and cpDNA sequences. Mol Phylogenet Evol 32:951-977.

Martín-Bravo S, H Meimberg, M Luceňo, W Märkl, V Valcárcel, C Bräuchler, P Vargas, G Heubl 2007 Molecular systematics and biogeography of Resedaceae based on ITS and trnL-F sequences. Mol Phylogenet Evol 44:1105-1120.

Martín Osorio VE, W Wildpret de la Torre, M del Arco Aguilar, PL Pérez de Paz, B Hernández Bolaños, O Rodríguez, JR Acebes, A García Gallo 2007 Estudio bioclimático y fitocenótico comparativo de la alta cumbre canaria: Tenerife-La Palma. Islas Canarias. Phytocoenologia 37:663-697.

Meco J, J Ballester, JF Betancort, S Cilleros, A Scaillet, H Gillou, JC Carracedo, et al 2006 Paleoclimatología del Neógeno en las Islas Canarias: Geliense, Pleistoceno y Holoceno. Ministerio de Medio Ambiente, Universidad de Las Palmas de Gran Canaria, Las Palmas.

Meco J, J Ballester, JF Betancort, A Scaillet, H Gillou, A Lomoschitz, JC Carracedo, et al 2005 Paleoclimatología del Neógeno en las Islas Canarias: Mioceno y Plioceno. Ministerio de Medio Ambiente, Universidad de Las Palmas de Gran Canaria, Las Palmas.

Meimberg H, T Abele, C Bräuchler C, JK McKay, PL Pérez de Paz, G Heubl 2006 Molecular evidence for adaptive radiation of $\mathrm{Mi}$ cromeria Benth. (Maliaceae) on the Canary Islands as inferred from chloroplast and nuclear DNA sequences and ISSR fingerprint data. Mol Phylogenet Evol 41:566-578.

Melzer S, F Lens, J Gennen, S Vanneste, A Rohde, T Beeckman 2008 Flowering-time genes modulate meristem determinacy and growth form in Arabidopsis thaliana. Nat Genet 40:1489-1492.

Mes THM, H 't Hart 1996 The evolution of growth-forms in the Macaronesian genus Aeonium (Crassulaceae) inferred from chloroplast DNA RFLPs and morphology. Mol Ecol 5:351-363.

Moore MJ, J Francisco-Ortega, A Santos-Guerra, RK Jansen 2002 Chloroplast DNA evidence for the roles of island colonization and extinction in Tolpis (Asteraceae: Lactuceae). Am J Bot 89:518526.

Mort ME, TR O'Leary, P Carillo-Reyes, T Nowell, JK Archibald, CP Randle 2010 Phylogeny and evolution of Crassulaceae: past, present and future. Schumannia 6:69-86.

Neves SS, MF Watson 2004 Phylogenetic relationships in Bupleurum (Apiaceae) based on nuclear ribosomal DNA ITS sequence data. Ann Bot 93:379-398.

Nordenstam B, PB Pelser, JW Kadereit, LE Watson 2009 Senecioneae.
Pages 503-525 in VA Funk, A Susanna, TF Stuessy, RJ Bayer, eds. Systematics, evolution, and biogeography of Compositae. International Association for Plant Taxonomy, Vienna.

Oberprieler C, S Himmelreich, M Källersjö, J Vallès, LE Watson, R Vogt 2009 Anthemideae. Pages 631-666 in VA Funk, A Susanna, TF Stuessy, RJ Bayer, eds. Systematics, evolution, and biogeography of Compositae. International Association for Plant Taxonomy, Vienna.

Oh S, S Park, KH Han 2003 Transcriptional regulation of secondary growth in Arabidopsis thaliana. J Exp Bot 54:2709-2722.

Olson ME 2007 Wood ontogeny as a model for studying heterochrony, with an example of paedomorphosis in Moringa (Moringaceae). Syst Biodivers 5:145-158.

Olson ME, S Carlquist 2001 Stem and root anatomical correlations with life form diversity, ecology, and systematics in Moringa (Moringaceae). Bot J Linn Soc 135:315-348.

Panero JL, RK Jansen, JA Clevinger 1999 Phylogenetic relationships of subtribe Ecliptinae (Asteraceae: Heliantheae) based on chloroplast DNA restriction site data. Am J Bot 66:413-427.

Pelser PB, AH Kennedy, EJ Tepe, JB Shidler, B Nordenstam, JW Kadereit, LE Watson 2010a Patterns and causes of incongruence between plastid and nuclear Senecioneae (Asteraceae) phylogenies. Am J Bot 97:856-873.

Pelser PB, B Nordenstam, JW Kadereit, LE Watson 2007 An ITS phylogeny of tribe Senecioneae (Asteraceae) and a new delimitation of Senecio L. Taxon 56:1077-1104.

Pelser PB, EJ Tepe, AH Kennedy, LE Watson $2010 b$ The fate of Robinsonia (Asteraceae): sunk in Senecio, but still monophyletic? Phytotaxa 5:31-46.

Percy DM, QCB Cronk 1997 Conservation in relation to mating system in Nesohedyotis arborea (Rubiaceae), a rare endemic tree from St Helena. Biol Conserv 80:135-145.

Potts R, AK Behrensmeyer 1992 Late Cenozoic terrestrial ecosystems. Pages 419-541 in AK Behrensmeyer, JD Damuth, WA DiMichele, R Potts, HD Sues, SL Wing, eds. Terrestrial ecosystems through time: evolutionary palaeoecology of terrestrial plants and animals. University of Chicago Press, Chicago.

Press JR, MJ Short, eds 1994 Flora of Madeira. Natural History Museum, London.

Rauscher JT 2002 Molecular phylogenetics of the Espeletia complex (Asteraceae): evidence from nrDNA ITS sequences of the closest relatives of an Andean adaptive radiation. Am J Bot 89:1074-1084.

Rønsted N, MW Chase, DC Albach, MA Bello 2002 Phylogenetic relationships within Plantago (Plantaginaceae): evidence from nuclear ribosomal ITS and plastid trnL-F sequence data. Bot J Linn Soc 139:323-338.

Sa'ad FZMA 1967 The Convolvulus species of the Canary Isles, the Mediterranean region and the Near and Middle East. Mededelingen van het Botanisch Museum en Herbarium Van Rijksuniversiteit te Utrecht, no 281. Bronder-Offset, Rotterdam. 288 pp.

Sanchez A, KA Kron 2008 Phylogenetics of Polygonaceae with an emphasis on the evolution of Eriogonoideae. Syst Bot 33:87-96.

Sanchez A, TM Schuster, KA Kron 2009 A large-scale phylogeny of Polygonaceae based on molecular data. Int J Plant Sci 170:10441055.

Schaefer H, C Heibl, SS Renner 2009 Gourds afloat: a dated phylogeny reveals an Asian origin of the gourd family (Cucurbitaceae) and numerous oversea dispersal events. Proc R Soc B 276:843-851.

Schilling EE, JL Panero, UH Eliasson 1994 Evidence from chloroplast DNA restriction site analysis on the relationships of Scalesia (Asteraceae: Heliantheae). Am J Bot 81:248-254.

Schrader J, J Nilsson, E Mellerowicz, A Berglund, P Nilsson, M Hertzberg, G Sandberg 2004 A high-resolution transcript profile across the wood-forming meristem of poplar identifies potential regulators of cambial stem cell identity. Plant Cell 6:2278-2292.

Schuster M, P Duringer, J-F Ghienne, P Vignaud, HT Mackaye, A 
Likius, M Brunet 2006 The age of the Sahara Desert. Science 311: 821.

Schütze P, H Freitag, K Weising 2003 An integrated molecular and morphological study of the subfamily Suaedoideae Ulbr. (Chenopodiaceae). Plant Syst Evol 239:257-286.

Schweingruber FH 1990 Anatomy of European woods. Haupt, Stuttgart.

Schweingruber FH, A Börner, E-D Schulze 2011 Atlas of stem anatomy in herbs, shrubs and trees. Vol 1. Springer, Heidelberg.

Scotland RW 2011 What is parallelism? Evol Dev 13:214-227.

Scott AJ 1977 Reinstatement and revision of Salicorniaceae J. Agardh (Caryophyllales). Bot J Linn Soc 75:357-374.

Sinnott EW, IW Bailey 1915 The evolution of herbaceous plants and its bearing on certain problems of geology and climatology. J Geol 23:289-306.

Smith SA, MJ Donoghue 2008 Rates of molecular evolution are linked to life history in flowering plants. Science 322:86-89.

Sperry JS, UG Hacke, TS Field, Y Sano, EH Sikkema 2007 Hydraulic consequences of vessel evolution in angiosperms. Int J Plant Sci 168: 1127-1139.

Spicer R, A Groover 2010 Evolution of development of vascular cambia and secondary growth. New Phytol 186:577-592.

Stefanović S, L Krueger, RG Olmstead 2002 Monophyly of the Convolvulaceae and circumscription of their major lineages based on DNA sequences of multiple loci. Am J Bot 89:1510-1522.

Strickler SR, A Bombarely, LA Mueller 2012 Designing a transcriptome next-generation sequencing project for a nonmodel plant species. Am J Bot 99:257-266.

Stutz HC 1989 Evolution of shrubs. Pages 323-340 in CM McKell, ed. The biology and utilization of shrubs. Academic Press, San Diego, CA.

Struwe L, JW Kadereit, J Klackenberg, S Nilsson, M Thiv, KB von Hagen, VA Albert 2002 Systematics, character evolution, and biogeography of Gentianaceae, including a new tribal and subtribal classification. Pages 21-309 in L Struwe, VA Albert, eds. Gentianaceae: systematics and natural history. Cambridge University Press, Cambridge.

Susanna A, N Garcia-Jacas 2009 Cardueae (Carduoideae). Pages 293-313 in VA Funk, A Susanna, TF Stuessy, RJ Bayer, eds. Systematics, evolution, and biogeography of Compositae. International Association for Plant Taxonomy, Vienna.

Susanna A, T Garnatje, N Garcia-Jacas 1999 Molecular phylogeny of Cheirolophus (Asteraceae: Cardueae-Centaureinae) based on ITS sequences of nuclear ribosomal DNA. Plant Syst Evol 214:147-160.

't Hart H, J Koek-Noorman 1989 The origin of woody Sedoideae (Crassulaceae). Taxon 38:535-544.

Thiede J, U Eggli 2007 Crassulaceae. Pages 83-122 in K Kubitzki, ed. The families and genera of vascular plants. Vol 9. Berberidopsidales, Buxales, Crossosomatales, Fabales p.p., Geraniales, Gunnerales, Myrtales p.p., Saxifragales, Vitales, Zygophyllales, Clusiaceae alliance, Passifloraceae alliance, Dilleniaceae, Huaceae, Picramniaceae, Sabiaceae. Springer, Berlin.

Thiv M, JW Kadereit 2002 Tribe Chironieae. Pages 108-137 in L Struwe, V Albert, eds. Gentianaceae: systematics and natural history. Cambridge University Press, Cambridge.

Thiv M, L Struwe, JW Kadereit 1999 The phylogenetic relationships and evolution of the Canarian laurel forest endemic Ixanthus viscosus (Aiton) Griseb. (Gentianaceae): evidence from matK and ITS sequences, and floral morphology and anatomy. Plant Syst Evol 218: 299-317.
Tilman D 1988 Resource competition and community structure. Princeton University Press, Princeton, NJ.

Tixier A, H Cochard, E Badel, A Dusotoit-Coucaud, S Jansen, S Herbette 2013 Arabidopsis thaliana as a model species for xylem hydraulics: does size matter? J Exp Bot 64:2295-2305.

Tomlinson PB, MH Zimmermann 1969 Vascular anatomy of monocotyledons with secondary growth: an introduction. J Arnold Arbor 50:159-179.

Turini FG, C Bräuchler, G Heubl 2010 Phylogenetic relationships and evolution of morphological characters in Ononis L. (Fabaceae). Taxon 59:1077-1090.

Upson T, S Andrews 2004 The genus Lavandula. Royal Botanic Gardens, Kew.

Vargas P 2007 Are Macaronesian plants island refugia or relict plant lineages? a molecular survey. Pages 297-314 in S Weiss and N Ferrand, eds. Phylogeography of southern European refugia: evolutionary perspectives on the origins and conservation of European biodiversity. Kluwer, Dordrecht.

Wagner WL, DR Herbst, SH Sohmer 1990 Manual of the flowering plants of Hawaii. Vols 1, 2. University of Hawaii Press and Bishop Museum Press, Honolulu.

Wahrmund U, H Heklau, M Röser, A Kärstner, E Vitek, F Ehrendorfer, KB von Hagen 2010 A molecular phylogeny reveals frequent changes of growth form in Carlina (Asteraceae). Taxon 59:367378.

Walker JB, Sytsma KJ, J Treutlein, M Wink 2004 Salvia (Lamiaceae) is not monophyletic: implications for the systematics, radiation, and ecological specializations of Salvia and tribe Mentheae. Am J Bot 91:1115-1125.

Wallace AR 1878 Tropical nature and other essays. Macmillan, London.

Warwick SI, K Mummenhoff, CA Saunder, MA Koch, IA Al-Shehbaz 2010 Closing the gaps: phylogenetic relationships in the Brassicaceae based on DNA sequence data of nuclear ribosomal ITS region. Plant Syst Evol 285:209-232.

Warwick SI, CA Sauder 2005 Phylogeny of tribe Brassiceae (Brassicaceae) based on chloroplast restriction site polymorphisms and nuclear ribosomal internal transcribed spacer and chloroplast trn $\mathrm{L}$ intron sequences. Can J Bot 83:467-483.

Weller SG, WL Wagner, AK Sakai 1995 A phylogenetic analysis if Schiedea and Alsinidendron (Caryophyllaceae: Alsinoideae): implications for the evaluation of breeding systems. Syst Bot 20:315337.

Wen Z-B, M-L Zhang, G-L Zhu, SC Sanderson 2010 Phylogeny of Salsoleae s.l. (Chenopodiaceae) based on DNA sequence data from ITS, $p s b \mathrm{~B}-p s b \mathrm{H}$, and $r b c \mathrm{~L}$, with emphasis on taxa of northwestern China. Plant Syst Evol 288:25-42.

Whittaker RJ, JM Fernández-Palacios 2010 Island biogeography: ecology, evolution, and conservation. 2nd ed. Oxford University Press, New York.

Whittaker RJ, KA Triantis, RJ Ladle 2008 A general dynamic theory of oceanic island biogeography. J Biogeogr 35:977-994.

Wilson PG 1980 A revision of the Australian species of Salicornieae (Chenopodiaceae). Nuytsia 3:3-154.

Yang Y, PE Berry 2011 Phylogenetics of the Chamaesyce clade (Euphorbia, Euphorbiaceae): reticulate evolution and long-distance dispersal in a prominent $\mathrm{C}_{4}$ lineage. Am J Bot 98:1486-1503.

Yesson C, NH Toomey, A Culham 2009 Cyclamen: time, sea and speciation biogeography using a temporally calibrated phylogeny. J Biogeogr 36:1234-1252. 